\title{
Growth Behavior of Intermetallic Compounds in Various Solder Joints Induced by Electromigration
}

\author{
Electromigration에 의한 다양한 솔더 접합부에서의 금속간 화합물 성장거동 \\ Sujong Kim*, Wonsik Hong**, Hyunbin Nam*,† and Namhyun Kang*,†† \\ *Department of Materials Science \& Engineering, Pusan National University, Busan, 46241, Korea \\ **Electronic Convergence Materials \& Device Research Center, Korea Electronics Technology Institute, \\ Seongnam, 13509, Korea \\ †Corresponding author: †hbnam12@pusan.ac.kr, ††nhkang@pusan.ac.kr \\ (Received December 22, 2020; Revised January 14, 2021; Accepted January 19, 2021)
}

\begin{abstract}
With the development of the fine pitch technology, the size of the solder bumps contacting the chip and the substrate has decreased, thereby significantly increasing the current density. As a result, intermetallic compounds (IMCs) are formed in solder bumps, and the formation/growth of Kirkendall voids is the main reason for failure, which is accelerated by electromigration. Therefore, various studies have been conducted to restrain the growth of IMCs and Kirkendall voids. This study summarizes the issues that should be considered when investigating the effects of electromigration on solder joints. The prediction and observation of the growth behavior of the IMCs is summarized for various solder bump joints. In addition, we provide an effective method for assisting the fine pitch technology.
\end{abstract}

Key Words: Electromigration, Solder bump joints, Intermetallic compounds, Kirkendall voids, Modeling

\section{Introduction}

There is an increasing demand for miniaturization and high performance of major products such as smart phones, 3D TVs and computers recently in the electronics industry, and technology for implementing a fine pitch for mounting many devices and terminals in a printed circuit board (PCB) substrate that connects a chip and a main board has been continuously developed in order to satisfy this demand ${ }^{1,2)}$. There was a problem that the current density applied to solder bump increased rapidly as the solder bump that connects the chip and the substrate became finer along with the development of fine pitch technology. The formation and growth of secondary phases induced by electromigration (EM) and thermo-migration (TM) are observed in the solder bump due to the increase in current density and temperature induced by joule heating, and this phenomenon leads to serious problems such as open-circuit failure due to rapid increase in electrical short and electrical resistance in the package ${ }^{3)}$. It has been reported that the formation and growth of Kirkendall voids and intermetallic compounds (IMC) formed between the solder and the substrate, which are the main causes of the problem, is accelerated due to electromigration $(\mathrm{EM})^{4,5)}$. $\mathrm{Pb}$-Snbased alloys are the alloys that were mainly applied to solder bumps in electronic devices, which have been actively used until 2006. However, studies on $\mathrm{Pb}$-free solders were continuously conducted and solders of various alloys have been developed with the emergence of lead poisoning problems ${ }^{6-8)}$. Although studies have been mainly conducted on intermetallic compounds and Kirkendall void growth behavior in $\mathrm{Sn}-\mathrm{Ag}$ alloy solder bumpers ${ }^{9,10)}$, studies on the EM effect in solder bump joints of Sn-Cu-based alloys have also been conducted recently ${ }^{11,12}$.

There is a trend of increasing and miniaturization of components mounted in a package due to microminiature fine-pitch technology with the application of Package 


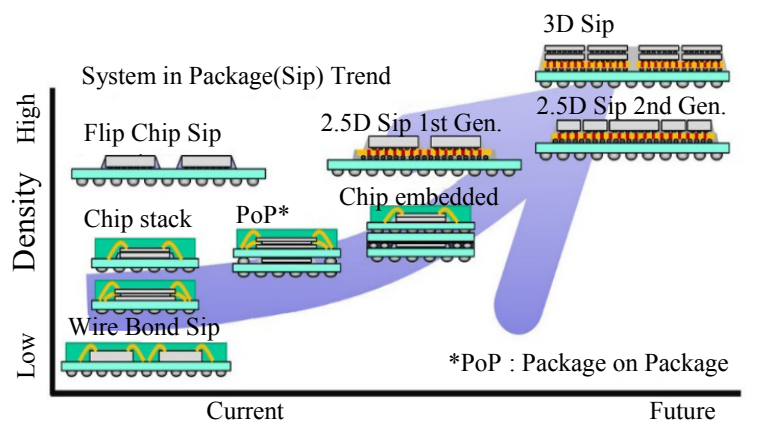

Fig. 1 Development trend of electronic packages ${ }^{15}$

on Package (PoP) and 3D System in Package (SiP) technologies as shown in Fig. $1^{13-15)}$. It is determined that the structure of the package needs to be changed and the solder bump material needs to be changed for an efficient method to inhibit the formation of defects since the current density applied to the solder bumps is rapidly increasing due to miniaturization. Therefore, the changes of voids and IMC in the joints according to EM effect in solder bump joints of various materials are summarized, and a study that predicts the change in IMC according to EM is introduced in this paper.

\section{Experimental and Modeling of Electromigration}

The growth of IMC due to EM is observed when a metal atom moves in the movement direction of electron due to an exchange of momentum when a moving electron collides with a metal atom when a current is stressed on the metal interconnect. The driving force of the movement of metal atoms due to EM includes an electron wind force and an electrostatic force. Electron wind force refers to the force that causes electrons that are accelerated by an electric field to collide with a metal atom and transfer momentum to the metal atom to move, and electrostatic force refers to the force that acts on an atom that has lost its valence electron and remains as an ion. Therefore, the effective driving force in $\mathrm{EM}$ is given as ${ }^{16)}$,

$$
J=\frac{C D}{k T} Z^{*} e \rho j
$$

where $\mathrm{J}$ is the EM flux, $\mathrm{C}$ is the concentration, $\mathrm{D}$ is the diffusivity, $Z^{*}$ is the effective charge number, $\mathrm{k}$ is the Boltzmann constant, $\mathrm{T}$ is the absolute temperature, $\mathrm{e}$ is the quantity of electric charge, $\rho$ is the specific resistance, and $\mathrm{j}$ is the current density.

Moreover, the concentration of metal atoms is actually changed according to time. The change in concentration over time is represented by Fick's second law ${ }^{16)}$.
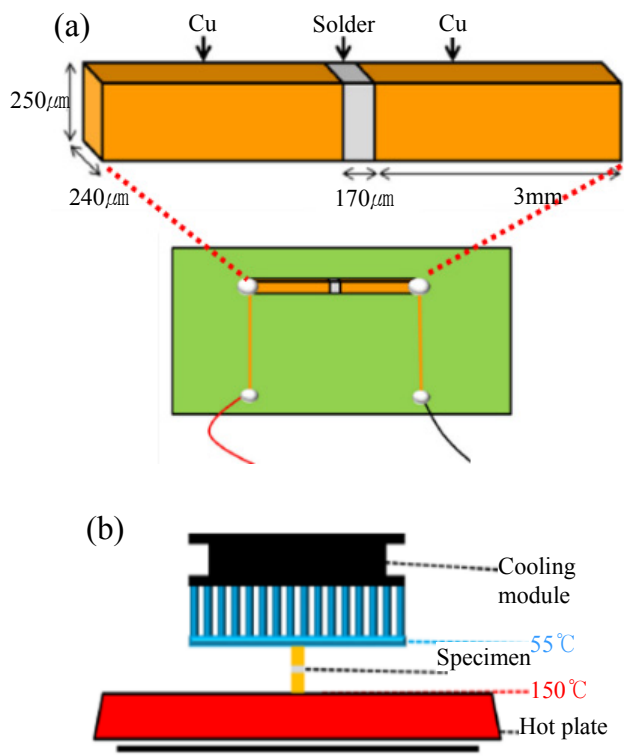

Fig. 2 Schematics diagram of (a) current stressing method for the EM experiments and (b) the TM experiments $^{17)}$

$\frac{\partial \mathrm{C}}{\partial \mathrm{t}}=-\frac{\partial \mathrm{J}}{\partial \mathrm{x}}$

The thickness of the growing IMC according to the current stressing time by calculating the EM flux at the formed IMC, the solder, and the metal atom can be predicted through Equations (1) and (2). The increase in electrical resistance and electrical short due to voids are indirectly predicted through the growth prediction modeling of IMC since the growth of IMC is related to the formation and growth of Kirkendall voids. The experimental verification is essential in order to verify that the predicted IMC thickness shows the same result when the current is actually stressed. A schematic diagram of current stressing for EM experiments is as shown in Fig. 2a and a schematic diagram of applying a temperature gradient for TM experiments is as shown in Fig. 2b. $\mathrm{Sn}-0.7 \mathrm{Cu}$ is the solder alloy that is used in Fig. 2, and DC source meter (IT6153) of ITECH was used as a power supply. The IMC is grown by stressing a current for a certain period of time through a power supply after constructing the EM experiment set as shown in Fig. 2a. Subsequently, an experimentally verified modeling result was produced by comparing the actual measured thickness of the IMC with the thickness of the IMC that is calculated through modeling.

\section{Results \& Discussion}

\subsection{Selection of Pb-free solder alloy}

It is required to apply an eco-friendly $\mathrm{Pb}$-free solder 
alloy with a melting point similar to that of $\mathrm{Sn}-\mathrm{Pb}$-based solder $\left(\sim 183{ }^{\circ} \mathrm{C}\right)$ and good electrical and mechanical properties as a consideration when selecting a $\mathrm{Pb}$-free solder alloy. Currently, a variety of Sn-based solders that can replace $\mathrm{Sn}-\mathrm{Pb}$ based solders are on the market, and $\mathrm{Sn}-\mathrm{Ag}-\mathrm{Cu}, \mathrm{Sn}-\mathrm{Ag}, \mathrm{Sn}-\mathrm{Cu}, \mathrm{Sn}-\mathrm{Zn}$, and $\mathrm{Sn}-\mathrm{Bi}-$ based solders are the most common $\mathrm{Pb}$-free solders ${ }^{18)}$. Most $\mathrm{Pb}$-free solder alloys consist of $\mathrm{Sn}$ as the main component and trace amounts of $\mathrm{Ag}, \mathrm{Cu}, \mathrm{Zn}, \mathrm{In}$, and $\mathrm{Bi}$ components $^{19)}$.

The eutectic point of the Sn-Zn-based eutectic composition solder is $199{ }^{\circ} \mathrm{C}$, which has the advantage that the conventional processor can be applied as it is since the melting point is similar to that of the conventional $\mathrm{Sn}-\mathrm{Pb}$ solder, and it has high strength, and good creep characteristics and thermal fatigue resistance. However, the commercialization is limited since it has fast reactivity with oxygen and the wettability with the substrate is poor $^{20)}$. It has been reported that the oxidation resistance can be improved by adding a trace amount of $\mathrm{Ag}$ and $\mathrm{Cu}$ since there is a disadvantage that the oxidation is accelerated although the wettability can be improved when a small amount of $\mathrm{Bi}$ is added to the $\mathrm{Sn}-\mathrm{Zn}$ eutectic alloy $^{21)}$.

The eutectic composition of $\mathrm{Sn}-\mathrm{Cu}$-based solder is $\mathrm{Sn}-0.7 \mathrm{Cu}$ and the eutectic point is $227^{\circ} \mathrm{C}$. The solder is deformed due to fatigue properties since $\mathrm{Sn}-0.7 \mathrm{Cu}$ solder has lower creep strength than Sn-Ag alloy, and studies and use have been increasing recently since it has been reported that the deformation of the solder resulting from the warpage defect due to the difference in the coefficient of thermal expansion between the chip and the substrate has excellent crack resistance in electronic packages $^{22)}$.

The eutectic composition of $\mathrm{Sn}-\mathrm{Ag}$-based solder is $\mathrm{Sn}-3.5 \mathrm{Ag}$ and the eutectic point is $221{ }^{\circ} \mathrm{C}$. The increase in the applied temperature of $\mathrm{Sn}-\mathrm{Ag}$ solder tends to decrease the surface tension and contact angle. Since the surface tension of Sn-Ag solder is higher than that of $\mathrm{Sn}-\mathrm{Pb}$ and the contact angle is also high $^{23)}$ it has been reported that $\mathrm{Sn}-\mathrm{Ag}$ solder has lower wettability than that of $\mathrm{Sn}-\mathrm{Pb}$ solder ${ }^{24)}$. For compensation, it has been reported that adding a trace amount of $\mathrm{Cu}$ to $\mathrm{Sn}$ Ag can improve the wettability and fatigue properties, and adding a trace amount of $\mathrm{Bi}$ improves the wettability $^{25,26)}$.

Currently, Sn-Ag-Cu-based solder is mainly applied in soldering and it can be defect generation and propagation sites since coarse $\mathrm{Ag}_{3} \mathrm{Sn}$ phase is formed when the content of $\mathrm{Ag}$ is increased. Therefore, $\mathrm{Sn}-3.0 \mathrm{Ag}-0.5 \mathrm{Cu}$ solder with a melting point of $217{ }^{\circ} \mathrm{C}$ has been established as a representative solder that can replace $\mathrm{Sn}-\mathrm{Pb}$ based solder ${ }^{27}$.

\subsection{Causes and characteristics of EM phenomenon in solder joints}

The metal atoms in the solder generally have a strong flow along the movement direction of electrons due to temperature rise when a current is stressed to a solder joint, and the IMC on the anode side grows rapidly as this flow of atoms becomes a driving force and movement of atoms in the same direction is activated. On the contrary, voids are formed by being accumulated on the cathode side, which leads to electrical short due to the growth of the voids and generation of cracks, since the diffusion rate of atoms around the vacancy is relatively reduced. This is a problem caused by the EM phenomenon and a schematic illustration of the EM phenomenon is as shown in Fig. $3^{28)}$. In addition, the internal temperature rises to $100^{\circ} \mathrm{C}$ or above due to the joule heating effect in the joint and the degradation phenomenon induced by EM is accelerated due to the current crowding phenomenon which is generated by structural problems of the solder joint. Therefore, it is difficult to predict the reliability of the solder joint lifespan, and many studies are being conducted to improve the joint lifespan. The studies that covered the effect of EM phenomenon on each solder joint are summarized in Table 1. The IMC formation behavior of the joints by solder material according to EM is described from the next section.

\subsubsection{Characteristics of Sn-Zn solder joints}

The microstructure of the $\mathrm{Sn}-9 \mathrm{Zn}$ alloy is as shown in Fig. 4. The as-cast solder of $\mathrm{Sn}-9 \mathrm{wt} \% \mathrm{Zn}$ eutectic composition did not form intermetallic compounds (Fig. 4a), and the microstructure of this alloy has a structure in which needle-like $\alpha-\mathrm{Zn}$ is finely dispersed in a matrix of $\beta$-Sn phase $\mathrm{e}^{29,30)}$. Moreover, oxidation resistance is significantly reduced when the $\mathrm{Zn}$-rich phase is increased in $\mathrm{Sn}-\mathrm{Zn}$ solder since $\mathrm{ZnO}$ is formed due to high reactivity with oxygen of the $\mathrm{Zn}$ element as shown in Fig. $4 b^{19)}$. A method to control the formation of $\mathrm{ZnO}$ is required in order to improve the bonding

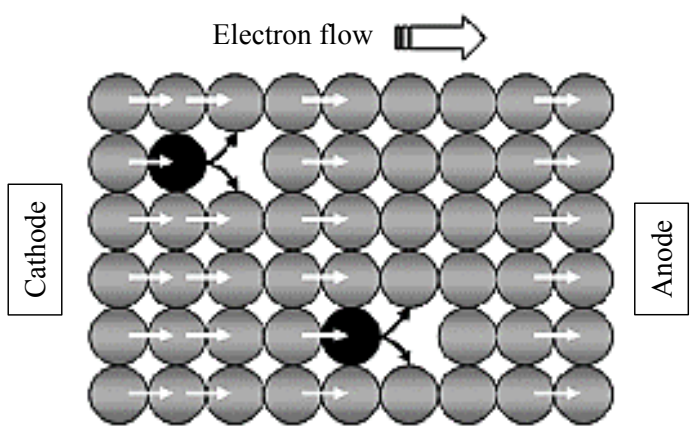

Fig. 3 Schematic illustration of elecromigration phenomena $^{28)}$ 
Table 1 Previous studies on EM for various solder joints

\begin{tabular}{|c|c|c|c|}
\hline Solder & Surface-finished & IMC & EM properies \\
\hline Sn-9Zn & $\mathrm{Cu}$ OSP & $\mathrm{Cu}_{5} \mathrm{Zn}_{8} / \mathrm{Cu}_{6} \mathrm{Sn}_{5}$ & $\begin{array}{l}\text { Anode : IMC decreased, Cathode : IMC increased (Reverse } \\
\text { polarity) }\end{array}$ \\
\hline $\mathrm{Sn}-0.7 \mathrm{Cu}$ & $\mathrm{Cu}$ OSP & $\mathrm{Cu}_{3} \mathrm{Sn} / \mathrm{Cu}_{6} \mathrm{Sn}_{5}$ & Anode : IMC increased, Cathode : IMC decreased (polarity) ${ }^{17)}$ \\
\hline $\mathrm{Sn}-0.7 \mathrm{Cu}$ & $\mathrm{Cu}$ OSP/ENIG & $\begin{array}{l}\mathrm{Cu}_{3} \mathrm{Sn} / \mathrm{Cu}_{6} \mathrm{Sn}_{5} \\
/(\mathrm{Ni}, \mathrm{Cu})_{6} \mathrm{Sn}_{5}\end{array}$ & Anode : IMC increased, Cathode : IMC decreased (polarity) ${ }^{42)}$ \\
\hline $\mathrm{Sn}-3.5 \mathrm{Ag}$ & $\mathrm{Cu}$ OSP & $\mathrm{Cu}_{3} \mathrm{Sn} / \mathrm{Cu}_{6} \mathrm{Sn}_{5}$ & $\begin{array}{l}\text { Anode : IMC increased, Cathode : IMC decreased (polarity) } \\
\text { Cathode : voids and cracks increased }\end{array}$ \\
\hline $\mathrm{Sn}-3.0 \mathrm{Ag}-0.5 \mathrm{Cu}$ & $\mathrm{Cu}$ OSP/ENIG & $\begin{array}{l}\mathrm{Cu}_{3} \mathrm{Sn} / \mathrm{Cu}_{6} \mathrm{Sn}_{5} \\
/(\mathrm{Ni}, \mathrm{Cu})_{6} \mathrm{Sn}_{5}\end{array}$ & $\begin{array}{l}\text { Anode : IMC increased, Cathode : IMC decreased (polarity) }{ }^{47)} \\
\mathrm{Cu} \text { OSP : thick IMC formed, ENIG : thin IMC formed }\end{array}$ \\
\hline
\end{tabular}
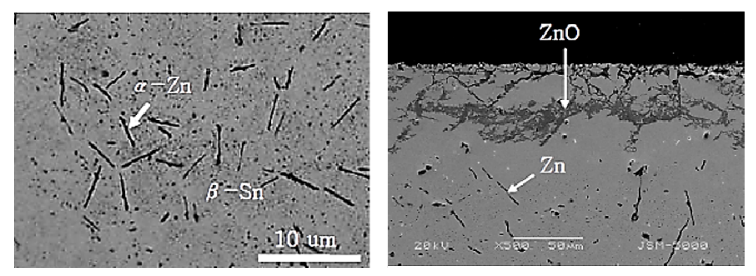

Fig. 4 Microstructure of Sn-9Zn alloy20): (a) the shape of each phase, (b) the formation of $\mathrm{ZnO}$

characteristics of $\mathrm{Sn}-\mathrm{Zn}$ solder.

$\mathrm{Xue}^{31)}$ observed the growth and component behavior of IMC through energy-dispersive spectroscopy (EDS) line/spot analysis, and $\mathrm{Guo}^{32)}$ analyzed the IMC behavior of the solder/ $\mathrm{Cu}$ substrate interface by adding $\mathrm{Ag}$ as a method to improve the oxidation resistance of $\mathrm{Sn}-\mathrm{Zn}$ solder. The components of the IMC layer between $\mathrm{Sn}-9 \mathrm{Zn}$ solder and $\mathrm{Cu}$ substrate $(\mathrm{Sn}-9 \mathrm{Zn} / \mathrm{Cu})$, and the growth behavior of IMC with increasing $\mathrm{Ag}$ content and aging time, respectively, are as shown in Figs. 5a and $5 \mathrm{~b}$. The IMC layer between $\mathrm{Sn}-9 \mathrm{Zn}$ solder and $\mathrm{Cu}$ substrate is mainly composed of $\mathrm{CuZn}_{5}$ and $\mathrm{Cu}_{5} \mathrm{Zn}_{8}$ (Fig. 5a), and the possibility of lowering the reliability of the solder joint is increased as the Sn component is decreased and the $\mathrm{Zn}$ component is increased significantly in the IMC layer through the EDS line analysis $^{31)}$. Therefore, the formation of $\mathrm{ZnO}$ was suppressed by adding Ag which has good reactivity with $\mathrm{Zn}$ in order to improve the oxidation resistance of Sn-9Zn. The IMC layer that is formed at the interface between the $\mathrm{Sn}-8.5 \mathrm{Zn}$ solder and the $\mathrm{Cu}$ substrate is composed of $\mathrm{AgZn}{ }_{3}$ and $\mathrm{Cu}_{5} \mathrm{Zn}_{8}$ due to the addition of $\mathrm{Ag}$ as shown in Fig. 5b, and the IMC layer of $\mathrm{Cu}_{5} \mathrm{Zn}_{8}$ tends to be decreased as the addition amount of $\mathrm{Ag}$ is increased, while the IMC layer tends to be increased as the aging time is increased ${ }^{32}$.

Zhang $^{33)}$ observed changes in the thickness of the anode and cathode sides of the IMC over time $(0,36$, 72 and $166 \mathrm{~h}$ ) with a current density of $3.87 \times 10^{3} \mathrm{~A} / \mathrm{cm}^{2}$ at $150{ }^{\circ} \mathrm{C}$, and the results are as shown in Fig. 6. The IMC layer tended to be decreased at $166 \mathrm{~h}$ of current stressing although the IMC layer thickness of $\mathrm{Cu}_{5} \mathrm{Zn}_{8}$ was increased at the anode side until after $72 \mathrm{~h}$ of current stressing depending on the aging time. The tendency to decrease after $166 \mathrm{~h}$ shows the opposite (a)

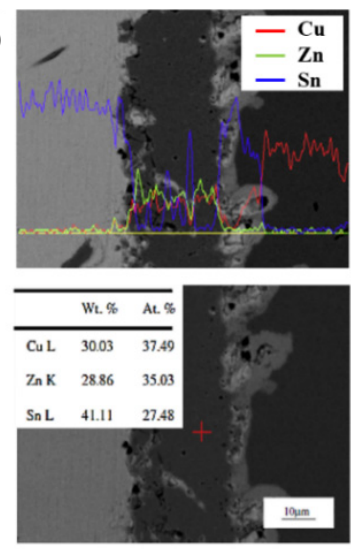

(b)
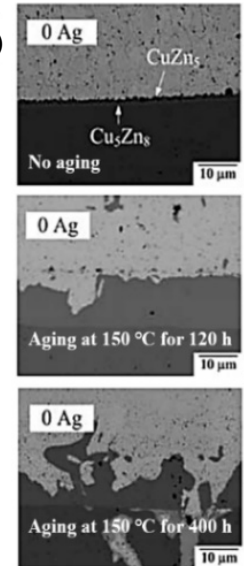
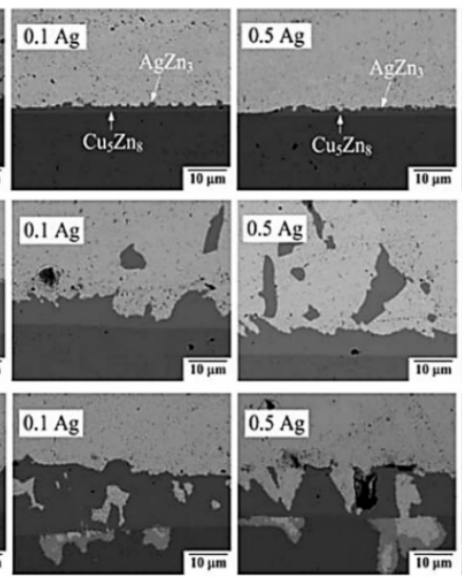
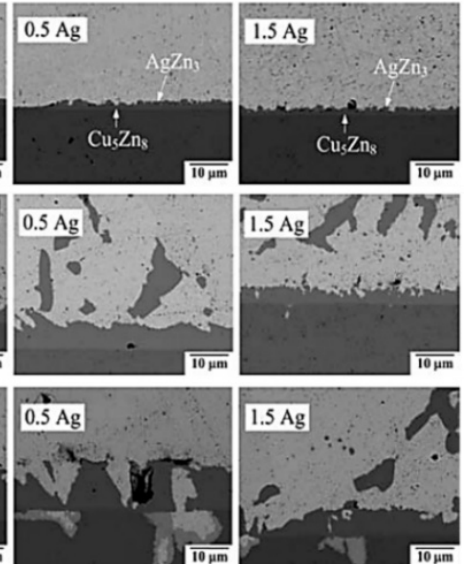

Fig. 5 Growth and component behavior of IMC in the interface between Sn-Zn solder and Cu substrate: (a) component behavior $^{31)}$, (b) effects of Ag content and aging temperature ${ }^{32)}$ 

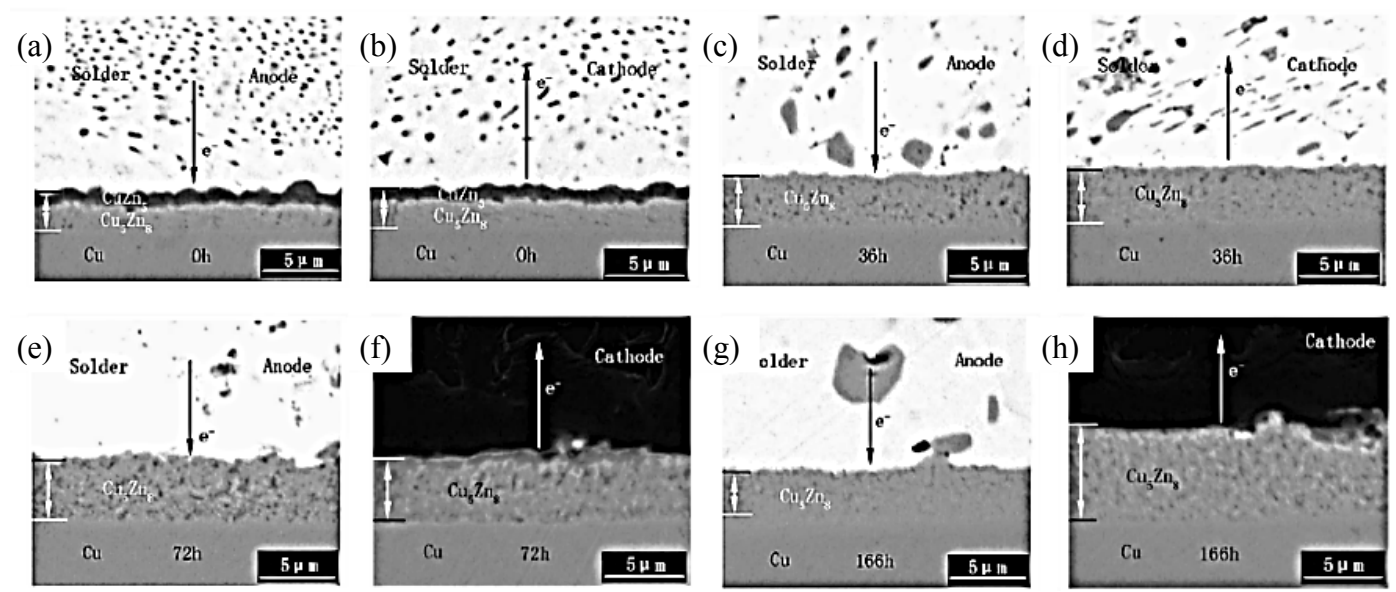

Fig. 6 SEM images of IMCs at the anode (left column) and the cathode (right column) for a current density of $3.87 \times 10^{3}$ $\mathrm{A} / \mathrm{cm}^{2}$ and $150{ }^{\circ} \mathrm{C}:(\mathrm{a}, \mathrm{b}) 0 \mathrm{~h},(\mathrm{c}, \mathrm{d}) 36 \mathrm{~h},(\mathrm{e}, \mathrm{f}) 72 \mathrm{~h}$, and $(\mathrm{g}, \mathrm{h}) 166 \mathrm{~h}^{33)}$

result from the general thermal effect although the increase in the thickness of the IMC layer is induced with the aging time. Moreover, the thickness of the IMC layer was increased until after $72 \mathrm{~h}$ of current stressing on the cathode side similar to the anode and the IMC thickness was increased sharply to about 5.4 $\mu \mathrm{m}$ after $166 \mathrm{~h}$ (Fig. 6h). The thickness of the IMC layer on the anode side was reduced to about $3.2 \mu \mathrm{m}$ (Fig. $6 \mathrm{~g})$. The formation of the thicker IMC layer on the cathode side is generally the opposite of the "polarity effect" and it has been reported that such a case of reverse polarity is often observed ${ }^{34,35)}$. $\mathrm{Zn}$ affects IMC formation in $\mathrm{Sn}-\mathrm{Zn}$ system. Sn atoms move to the anode due to electron wind force when current is stressed. On the contrary, it is determined that reverse polarity is observed since the back stress acts and the $\mathrm{Zn}$ atoms move toward the cathode.

Fig. 6 SEM images of IMCs at the anode (left column) and the cathode (right column) for a current density of $3.87 \times 10^{3} \mathrm{~A} / \mathrm{cm}^{2}$ and $150{ }^{\circ} \mathrm{C}$ : (a,b) $0 \mathrm{~h},(\mathrm{c}, \mathrm{d})$ $36 \mathrm{~h},(\mathrm{e}, \mathrm{f}) 72 \mathrm{~h}$, and (g,h) $166 \mathrm{~h}^{33)}$.
Huang ${ }^{36)}$ observed the change in the thickness of the IMC layer due to liquid-solid electromigration (L-S EM) according to the current stressing time at $250{ }^{\circ} \mathrm{C}$ with a current density of $1.2 \times 10^{4} \mathrm{~A} / \mathrm{cm}^{2}$ through insitu images and the results are as shown in Fig. 7. First, air bubbles were slightly formed at the solder interface and the solder began to melt before the current is stressed ( $0 \mathrm{~min})$ (Fig. 7a), and continuous IMC layers were formed at each interface of anode and cathode after 5 min of L-S EM (Fig. 7b). After 8 min, the IMC layer of the anode marked with a white dotted line was dissolved or $\mathrm{Cu}$ was consumed although IMC was grown at the cathode-side interface that is marked with a yellow circle. In addition, the IMC layer that is formed at the anode side interface was extremely thin although the IMC layer that is formed on the cathode side grew thicker up to the $\mathrm{Sn}-9 \mathrm{Zn}$ solder as the L-S EM time increased. These results show that the dissolution of $\mathrm{Cu}$ on the anode side is accelerated although the growth of the IMC layer is induced due to the limited consumption of $\mathrm{Cu}$ on the cathode side.

$\mathrm{Kuo}^{37)}$ observed the IMC behavior that is formed at

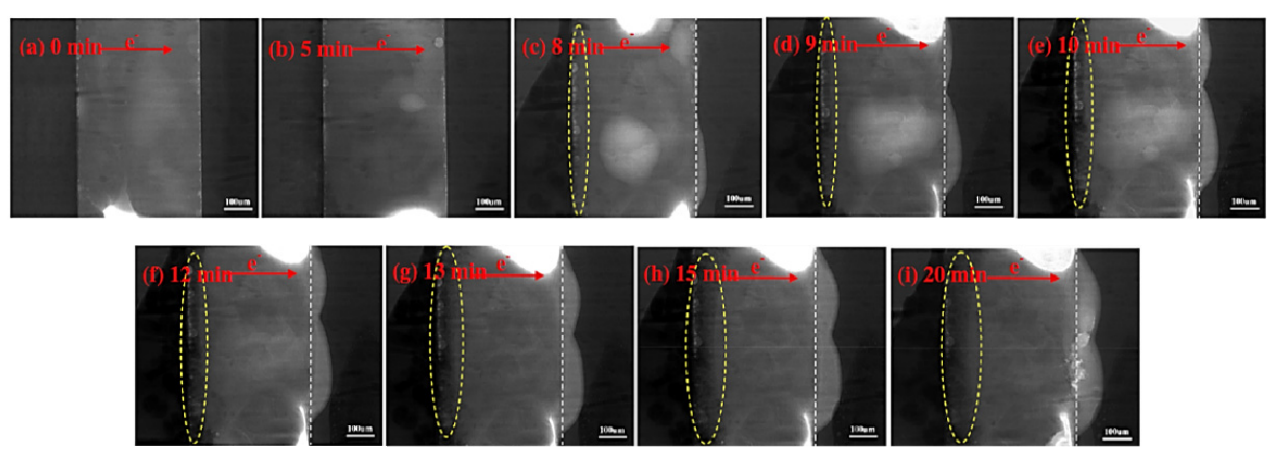

Fig. 7 In situ observation of L-S EM of the $\mathrm{Cu} / \mathrm{Sn}-9 \mathrm{Zn} / \mathrm{Cu}$ interconnect under a current density of $1.2 \times 10^{4} \mathrm{~A} / \mathrm{cm}^{2}$ at $250{ }^{\circ} \mathrm{C}$ for (a) $0 \mathrm{~min}$, (b) $5 \mathrm{~min}$, (c) $8 \mathrm{~min}$, (d) $9 \mathrm{~min}$, (e) $10 \mathrm{~min}$, (f) $12 \mathrm{~min}$, (g) $13 \mathrm{~min}$, (h) $15 \mathrm{~min}$, and (i) $20 \mathrm{~min}$, respectively $^{36 \text { ) }}$ 

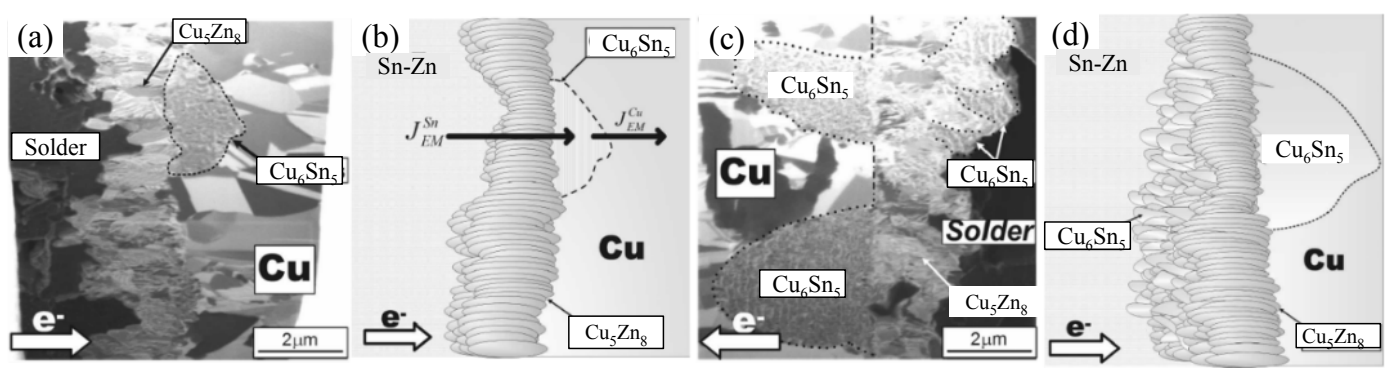

Fig. 8 TEM images for anode area of $\mathrm{Sn}-\mathrm{Zn}$ solder $/ \mathrm{Cu}$ interface after current stressing at $1.0 \times 10^{3} \mathrm{~A} / \mathrm{cm}^{2}$ : (a) $100 \mathrm{~h},(\mathrm{~b})$ mechanism at $100 \mathrm{~h},(\mathrm{c}) 185 \mathrm{~h}$, and (d) mechanism at $185 \mathrm{~h}^{37)}$

the $\mathrm{Sn}-9 \mathrm{Zn}$ solder and $\mathrm{Cu}$ interface on the anode side through the TEM image of the specimen that is prepared with focused ion beam (FIB) after 100 and $185 \mathrm{~h}$ of stressing current at $130{ }^{\circ} \mathrm{C}$ with a current density of $1.0 \times 10^{3} \mathrm{~A} / \mathrm{cm}^{2}$ as shown in Fig. 8. Huang ${ }^{36)}$ mechanically explained the accelerated dissolution and consumption of $\mathrm{Cu}$ on the anode side as shown in Fig. 8. The behavior and mechanism of IMC formation at the solder/Cu interface on the anode side with $100 \mathrm{~h}$ of current stressing are as shown in Figs $8 \mathrm{a}$ and $8 \mathrm{~b}$. A layered $\mathrm{Cu}_{5} \mathrm{Zn}_{8}$ IMC in the longitudinal direction was formed at the solder/Cu interface on the anode side and the IMC of $\mathrm{Cu}_{6} \mathrm{Zn}_{5}$ was observed at the $\mathrm{Cu}_{5} \mathrm{Zn}_{8} \mathrm{IMC} / \mathrm{Cu}$ interface (Fig. 8a). The $\mathrm{Sn}$ atoms move rapidly through the $\gamma-\mathrm{Cu}_{5} \mathrm{Zn}_{8}$ crystal grain boundary due to EM since the grain boundary of $\gamma-\mathrm{Cu}_{5} \mathrm{Zn}_{8}$ phase in the longitudinal direction is almost parallel to the movement direction of the electrons when a current is stressed. Therefore, IMC of $\mathrm{Cu}_{6} \mathrm{Sn}_{5}$ is formed through the accumulation of $\mathrm{Sn}$ and the interaction of $\mathrm{Cu}$ at the $\mathrm{Cu}_{5} \mathrm{Zn}_{8} \mathrm{IMC} / \mathrm{Cu}$ interface on the anode side (Fig. 8b). The consumption of $\mathrm{Cu}$ on the anode side is relatively severe due to the growth of the $\mathrm{Cu}_{6} \mathrm{Sn}_{5}$ IMC layer after $185 \mathrm{~h}$ of current stressing (Fig. 8c). Since the diffusion of $\mathrm{Cu}$ in $\mathrm{Sn}$ is more dominant than the diffusion of $\mathrm{Sn}$ in $\mathrm{Cu}$, it is formed in the $\mathrm{Cu}$ layer on the anode side after forming $\mathrm{Cu}_{6} \mathrm{Sn}_{5}$ IMC at the $\mathrm{Cu}_{5} \mathrm{Zn}_{8}$ IMC/Cu interface as $\mathrm{Sn}$ moves to the $\mathrm{Cu}$ layer on the anode side through EM, thereby explaining the consumption of $\mathrm{Cu}$ (Fig. 8d).

\subsubsection{Characteristics of $\mathrm{Sn}$-Cu solder joints}

The microstructure of $\mathrm{Sn}-0.7 \mathrm{Cu}$ alloy is composed of $\beta$-Sn and $\mathrm{Cu}_{6} \mathrm{Sn}_{5} / \beta-\mathrm{Sn}$ eutectic composition, and the microstructure of this alloy is as shown in Fig. $9^{38)}$. Hung $^{39)}$ observed the microstructure change in $\mathrm{Sn}-x \mathrm{Cu}$ according to the $\mathrm{Cu}$ content, and the $\beta$-Sn phase tended to become finer although the IMC of $\mathrm{Cu}_{6} \mathrm{Sn}_{5}$ was increased as the $\mathrm{Cu}$ content was increased. An appropriate addition is required since the melting point of the solder is also increased significantly depending on the $\mathrm{Cu}$ content although a large amount of IMC that
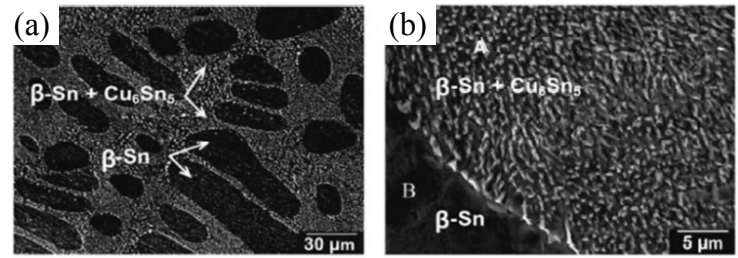

Fig. 9 Microstructure of $\mathrm{Sn}-0.7 \mathrm{Cu}$ alloy ${ }^{38)}$ : (a) the shape of each phase, (b) magnified image of the interface between $\beta$-Sn and eutectic mixture

is evenly dispersed in the matrix serves as a strengthening mechanism. In addition, Yang ${ }^{40)}$ and El-Daly ${ }^{41)}$ conducted studies to improve the electrical/thermal conductivity and solder joint properties of the solder joint by adding $\mathrm{Al}$ and $\mathrm{Ag}$ components to the $\mathrm{Sn}-0.7 \mathrm{Cu}$ alloy, and observed that the fraction of various IMCs increased and the $\beta$-Sn phase became finer.

Baek $^{17)}$ observed the effects of EM and TM that are related to the formation and growth of IMC in the solder joint of $\mathrm{Sn}-0.7 \mathrm{Cu}$. The specimens were prepared for accurate implementation of current straightness and temperature gradient, and were compared with the results of IMC growth modeling. The change in IMC thickness due to EM after 0-300 h of current stressing with a constant current of $6 \mathrm{~A}$ and a current density of $10 \mathrm{kA} / \mathrm{cm}^{2}$ at $120{ }^{\circ} \mathrm{C}$ is as shown in Fig. 10a. The IMC layer that is formed at the $\mathrm{Sn}-0.7 \mathrm{Cu} / \mathrm{Cu}$ interface is mainly composed of $\mathrm{Cu}_{6} \mathrm{Sn}_{5}$ and $\mathrm{Cu}_{3} \mathrm{Sn}$, and the IMC layer became thicker as the current stressing time is increased. In particular, the growth of IMC and void showed a close correlation with the electrical short since the void fraction at the interface between the IMC layer of $\mathrm{Cu}_{6} \mathrm{Sn}_{5}$ and the $\mathrm{Sn}-0.7 \mathrm{Cu}$ solder was increased simultaneously after $200 \mathrm{~h}$ of current stressing. The change in the thickness of the IMC layer due to TM after maintaining the temperature for $0-300 \mathrm{~h}$ under heating and cooling conditions of $55 / 150{ }^{\circ} \mathrm{C}$ is as shown in Fig. 10b. The IMC formed at the solder/Cu interface due to TM is composed of $\mathrm{Cu}_{6} \mathrm{Sn}_{5}$ and $\mathrm{Cu}_{3} \mathrm{Sn}$ as shown in Fig. 10a, and the IMC layer tends to be slightly increased as the temperature holding time is 
(a)

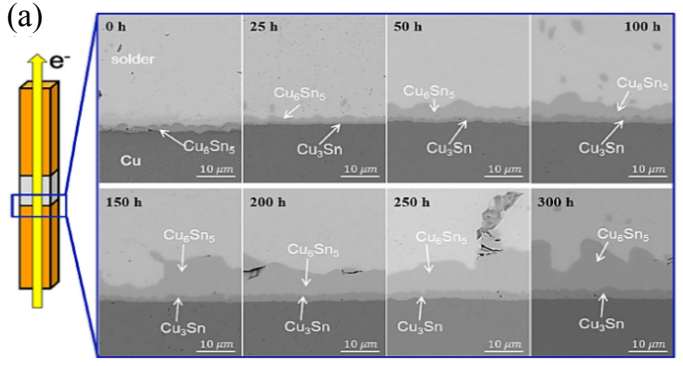

(b)

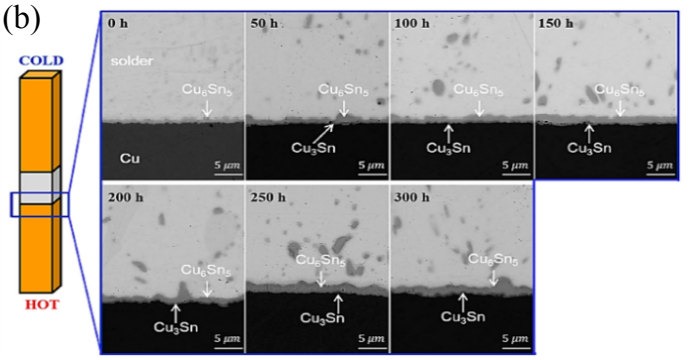

Fig. 10 SEM image of an IMC grown by (a) EM and (B) $\mathrm{TM}^{17)}$

(a)



Fig. 11 Schematic diagram of (a) solder joint and (b) IMC area measurement to calculate IMC thickness ${ }^{42}$

increased. However, it was observed that EM has a greater influence than TM on the thickness change in the IMC layer that is formed at the solder/ $\mathrm{Cu}$ interface. $\mathrm{Heo}^{42)}$ observed the IMC growth behavior according to the current density and stressing time at the solder joint that connects the $\mathrm{Cu}$ land of the $\mathrm{Si}$ wafer and the electroless nickel-immersion gold (ENIG) of the substrate, and the schematic diagram of the solder joint and the method of measuring the IMC thickness are as shown in Figs 11a and 11b, respectively. The change in IMC thickness growing at the interface of the solder joint after $0-300 \mathrm{~h}$ of current stressing at $150{ }^{\circ} \mathrm{C}$ with current densities of $1.3 \times 10^{4} \mathrm{~A} / \mathrm{cm}^{2}$ and $1.9 \times 10^{4} \mathrm{~A} / \mathrm{cm}^{2}$ are as shown in Figs. 12a and 12b, respectively. As a result of the experiment on the change in the thickness of IMC according to the current density and stressing time, $\mathrm{Cu}_{3} \mathrm{Sn}$ and $\mathrm{Cu}_{6} \mathrm{Sn}_{5}$ IMC were grown as the current stressing time was increased and the growth rate of $\mathrm{Cu}_{6} \mathrm{Sn}_{5}$ IMC was faster than that of $\mathrm{Cu}_{3} \mathrm{Sn}$. In addition, the growth rate of IMC was observed to be about 2-3 times, which is higher than the current density increase rate of 1.5 times, as the current density was increased from $1.3 \times 10^{4} \mathrm{~A} / \mathrm{cm}^{2}$ to $1.9 \times 10^{4} \mathrm{~A} / \mathrm{cm}^{2}$. Therefore, it was found that the aging and TM effects due to Joule heating effect need to be considered in addition to EM in the phenomena related to the growth of IMC when the current density is increased ${ }^{42)}$.

\subsubsection{Characteristics of Sn-Ag solder joints}

$\mathrm{Sn}-3.5 \mathrm{wt} \% \mathrm{Ag}$ eutectic alloy is composed of almost pure $\beta$-Sn and $\varepsilon-\mathrm{Ag}_{3} \mathrm{Sn}$ phase microstructure. The needle-

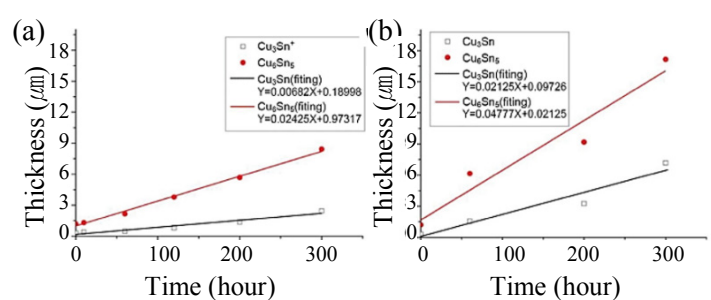

Fig. 12 IMC thickness for applying the various current densities $^{42)}$ : (a) $1.3 \times 104 \mathrm{~A} / \mathrm{cm}^{2}$, (b) $1.9 \times 10^{4} \mathrm{~A} / \mathrm{cm}^{2}$

like $\mathrm{Ag}_{3} \mathrm{Sn}$ grows along the solidification direction in Sn-matrix according to the two-stage (CR1-CR2) cooling, and nucleation is promoted if the cooling rate is increased during soldering (P1), which hinders the growth of $\mathrm{Ag}_{3} \mathrm{Sn}$ and shows a finely dispersed structure as shown in Fig. 13 ${ }^{43}$. It has the greatest mechanical strength in the eutectic composition of $3.5 \mathrm{wt} \% \mathrm{Ag}$ with the dispersion strengthening effect due to the characteristics of the finely dispersed $\varepsilon-\mathrm{Ag}_{3} \mathrm{Sn}$ phase ${ }^{25)}$. The IMC layer between the $\mathrm{Sn}-3.5 \mathrm{Ag}$ solder and the $\mathrm{Cu}$ substrate $(\mathrm{Sn}-3.5 \mathrm{Ag} / \mathrm{Cu})$ is mainly composed of $\mathrm{Cu}_{3} \mathrm{Sn}$ and $\mathrm{Cu}_{6} \mathrm{Sn}_{5}$, and there is an $\mathrm{Ag}_{3} \mathrm{Sn}$ phase dispersed in a fibrous form. The study results that are related to the effect of the Ag content and reflow temperature in the solder on the IMC behavior in Sn-Ag solder joints are as shown in Fig. 14. It has been reported that the average number of grains of $\mathrm{Cu}_{6} \mathrm{Sn}_{5}$ is increased as the concentration of $\mathrm{Ag}$ is increased and the grain width is decreased as the reflow temperature is decreased ${ }^{44)}$.

Jung $^{45)}$ investigated the growth behavior of IMC and Kirkendall voids on the anode and cathode sides according to the current stressing time of the $\mathrm{Cu} / \mathrm{Sn}-3.5 \mathrm{Ag} / \mathrm{Cu}$ junction. The IMC growth behavior of the Sn-3.5Ag/ $\mathrm{Cu}$ solder interface with time variation of $0-200 \mathrm{~h}$

Table 2 Primary and secondary cooling rates at measurement position P1-P4 in continuous cooling experiment $^{43)}$

\begin{tabular}{|c|c|c|c|c|}
\hline Position & P1 & P2 & P3 & P4 \\
\hline CR1 $\left({ }^{\circ} \mathrm{C} / \mathrm{s}\right)$ & 263.6 & 116 & 43.9 & 27.1 \\
\hline $\mathrm{CR} 2\left({ }^{\circ} \mathrm{C} / \mathrm{s}\right)$ & 113.6 & 42.1 & 30.8 & 21.6 \\
\hline
\end{tabular}



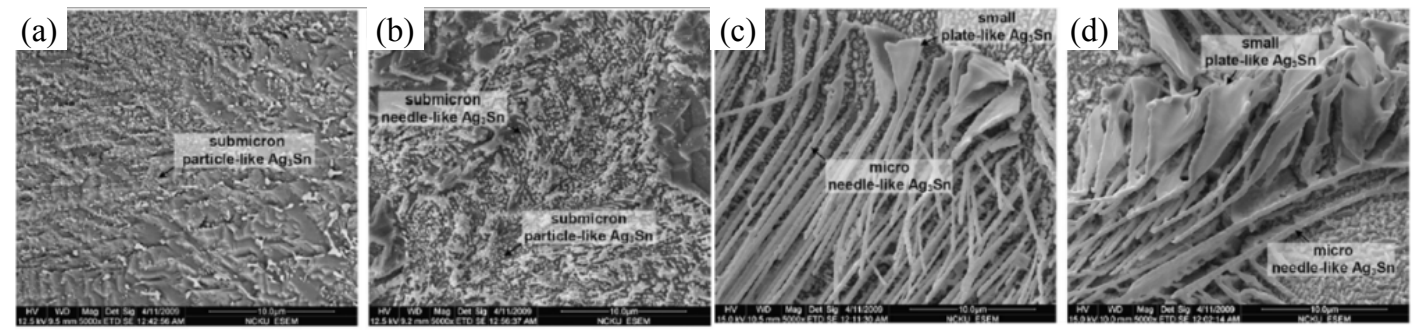

Fig. 13 3D SEM morphologies of Ag3Sn compounds at measurement positions P1-P4 in continuous cooling experiment ${ }^{43)}$ : (a) P1, (b) P2, (c) P3, and (d) P4
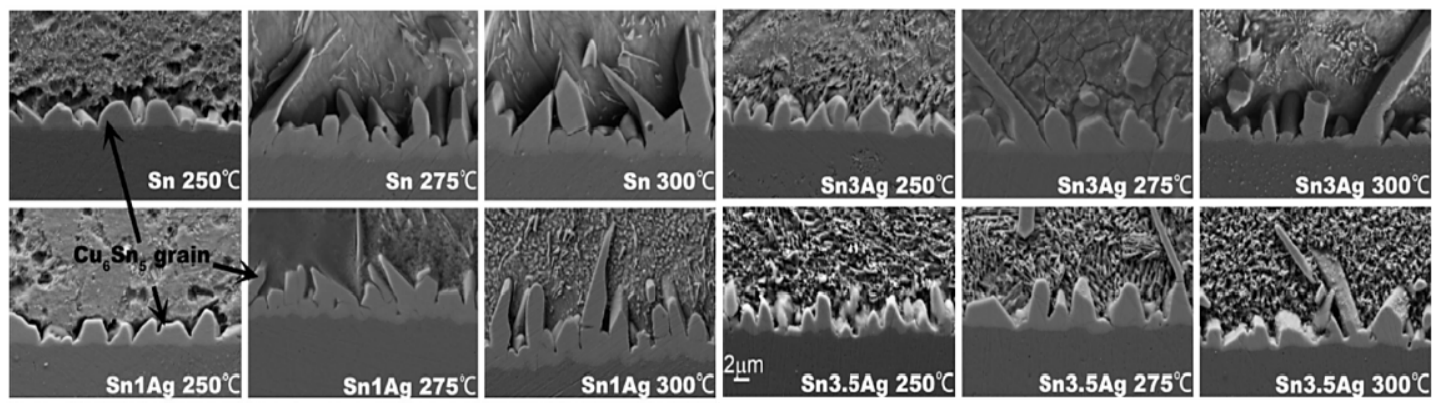

Fig. 14 Cross-sectional SEM images of air-cooled solder alloys to indicate $\mathrm{Cu}_{6} \mathrm{Sn}_{5}$ grains for various magnitudes of pre-cooled isothermal reflow temperature and $\mathrm{Ag}$ concentrations ${ }^{44)}$

(a)
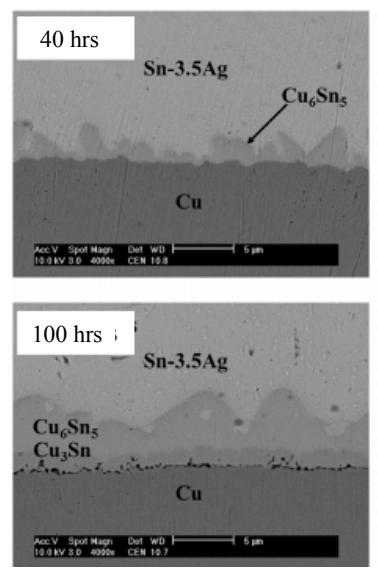
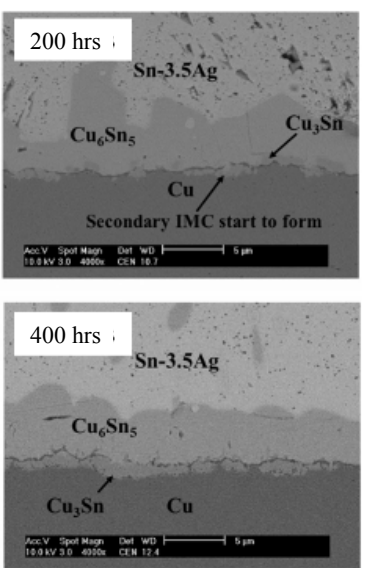

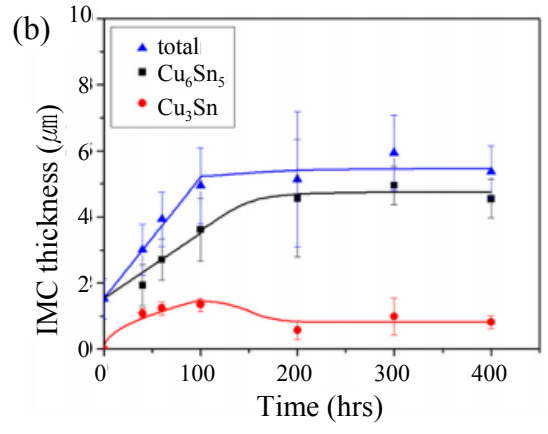

Fig. $15 \mathrm{Sn}-3.5 \mathrm{Ag} / \mathrm{Cu}$ solder joint aged at $150{ }^{\circ} \mathrm{C}$ without electricity flow for 0-400 h: (a) Cross-sectional SEM images, (b) thickening of IMC at the solder joint ${ }^{45}$

without current stressing at $150{ }^{\circ} \mathrm{C}$ is as shown in Fig. 15. The main IMCs, $\mathrm{Cu}_{3} \mathrm{Sn}$ and $\mathrm{Cu}_{6} \mathrm{Sn}_{5}$ layers, were grown as the aging time was increased, and most of the Kirkendall voids were formed at the $\mathrm{Cu}_{3} \mathrm{Sn} / \mathrm{Cu}$ interface after $100 \mathrm{~h}$ of aging. The increase in aging time causes continuous nucleation and growth of voids, and voids completely cover the $\mathrm{Cu}_{3} \mathrm{Sn} / \mathrm{Cu}$ interface after $200 \mathrm{~h}$. The position of the void formed at the $\mathrm{Cu}_{3} \mathrm{Sn} / \mathrm{Cu}$ interface is moved to the $\mathrm{Cu}_{3} \mathrm{Sn} / \mathrm{Cu}_{6} \mathrm{Sn}_{5}$ interface after $400 \mathrm{~h}$. The reason is that $\mathrm{Cu}_{3} \mathrm{Sn}$ is converted to $\mathrm{Cu}_{6} \mathrm{Sn}_{5}$ and new $\mathrm{Cu}_{3} \mathrm{Sn}$ is formed at the $\mathrm{Cu}_{6} \mathrm{Sn}_{5} / \mathrm{Cu}$ interface.

The IMC growth behavior and Kirkendall void fraction of anode/cathode after 40-150 h of current stressing at
$150{ }^{\circ} \mathrm{C}$ with a current density of $1 \times 10^{4} \mathrm{~A} / \mathrm{cm}^{2}$ are as shown in Fig. 16. It was found that EM had a polarity effect not only on the thickness of the IMC but also on the fraction of Kirkendall voids. The polarity effect of the IMC thickness is mainly caused by $\mathrm{Cu}_{6} \mathrm{Sn}_{5}$ since there is no significant difference in thickness of $\mathrm{Cu}_{3} \mathrm{Sn}$ depending on the current stressing time, and the growth rate on the cathode side is reduced although the growth of IMC and void is accelerated on the anode side. The formation and growth behavior of Kirkendall voids according to the current stressing time on the anode side were almost similar to the case where there was no current stressing. However, the voids were formed at 
(a)
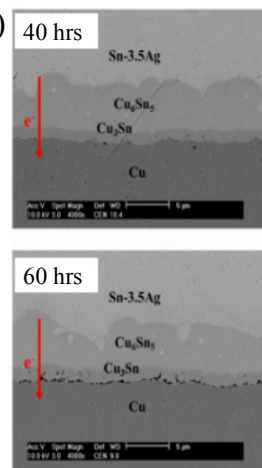
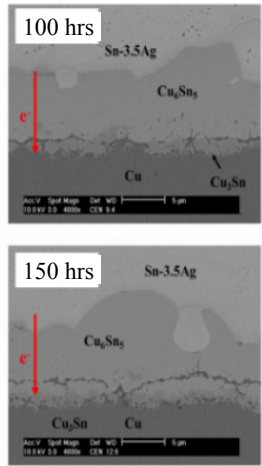

(b)
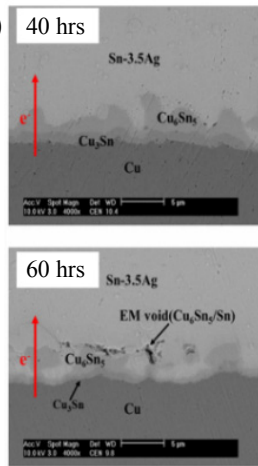
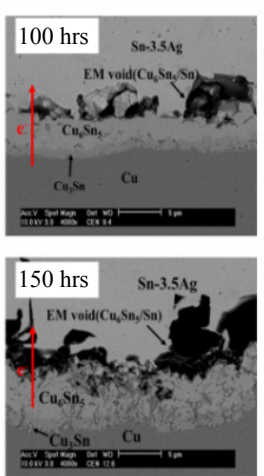

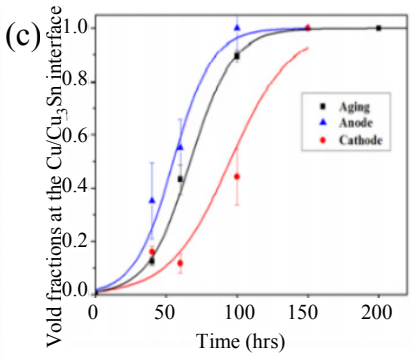$$
\text { Time (hrs) }
$$

Fig. 16 Cross-sectional SEM images of $\mathrm{Sn}-3.5 \mathrm{Ag} / \mathrm{Cu}$ solder joint aged at $150{ }^{\circ} \mathrm{C}$ under the electric current density of $1 \times$ $1^{04} \mathrm{~A} / \mathrm{cm}^{2}$ : (a) the anode side, (b) the cathode side, (c) fraction of Kirkendall void after $40-150 \mathrm{~h}^{45}$ )

the $\mathrm{Cu}_{3} \mathrm{Sn} / \mathrm{Cu}$ interface on the cathode side, while Kirkendall voids accounted for most of the $\mathrm{Cu}_{6} \mathrm{Sn}_{5} / \mathrm{Sn}$ interface after $100 \mathrm{~h}$, and the micro cracks were formed at $150 \mathrm{~h}$ since the Kirkendall void was saturated at the $\mathrm{Cu}_{6} \mathrm{Sn}_{5} / \mathrm{Sn}$ interface. It has been reported that the formation and growth of Kirkendall voids affect the lifespan of the solder joints ${ }^{3)}$.

\subsubsection{Sn-Ag-Cu solder joint characteristics}

$\mathrm{Sn}-3.5 \mathrm{wt} \% \mathrm{Ag}-0.7 \mathrm{wt} \% \mathrm{Cu}$ eutectic alloy generally has a microstructure similar to that of $\mathrm{Sn}-3.5 \mathrm{Ag}$ alloy. There is a crystalline phase of $\eta-\mathrm{Cu}_{6} \mathrm{Sn}_{5}$ in the eutectic phase of $\beta$-Sn and $\mathrm{Sn} / \mathrm{Ag}_{3} \mathrm{Sn}$, and in the $\varepsilon-\mathrm{Ag}_{3} \mathrm{Sn}$ phase, which are constituent structures, due to the addition of a trace amount of $\mathrm{Cu}$ as shown in Fig. 17 $7^{46)}$. Therefore, $\mathrm{Sn}-3.0 \mathrm{Ag}-0.5 \mathrm{Cu}$ alloy has been established as a representative alloy in order to prevent the formation of coarse $\mathrm{Ag}_{3} \mathrm{Sn}$ phases in a composition with high $\mathrm{Ag}$ content.

The IMC layer between the $\mathrm{Sn}-3.0 \mathrm{Ag}-0.5 \mathrm{Cu}$ solder and the $\mathrm{Cu}$ substrate $(\mathrm{SAC} 305 / \mathrm{Cu})$ is mainly configured of $\mathrm{Cu}_{3} \mathrm{Sn}$ and $\mathrm{Cu}_{6} \mathrm{Sn}_{5}$, and there is a eutectic phase of $\mathrm{Sn} / \mathrm{Ag}_{3} \mathrm{Sn}$ as shown in Fig. 18a ${ }^{47)}$. SEM images and schematic diagrams of the microstructure changes at (a)
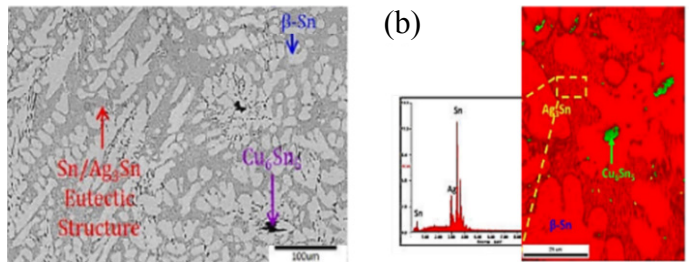

Fig. 17 Microstructure of SAC305 joint: (a) microstructure at solder matrix, (b) EBSD image with inverse pole figure (IPF) ${ }^{47)}$

the boundary of the IMC layer/matrix according to the cooling method (cooling rate) are as shown in Figs. $18 \mathrm{~b}$ and $18 \mathrm{c}$. The size and fraction of $\mathrm{Ag}_{3} \mathrm{Sn}$ and $\mathrm{Cu}_{6} \mathrm{Sn}_{5}$ intermetallic compounds in the matrix are reduced due to the fast cooling rate, and the IMC $\left(\mathrm{Cu}_{6} \mathrm{Sn}_{5}\right)$ layer in the SAC305/Cu boundary is also reported to be reduced ${ }^{48)}$.

$\mathrm{Kim}^{49}$ investigated the effect of heat treatment according to the upper/lower part of the SAC305 solder joint and the behavior growth of IMC due to current stressing. Immediately after soldering, IMCs of $(\mathrm{Cu}, \mathrm{Ni})_{6} \mathrm{Sn}_{5}$, and $\mathrm{Cu}_{6} \mathrm{Sn}_{5} / \mathrm{Cu}_{3} \mathrm{Sn}$ were formed at the joint interface in the ENIG surface finish of the upper joint and in the organic solderability preservative (OSP) surface finish of the lower joint, respectively (Fig. 19a). The IMC of (a)

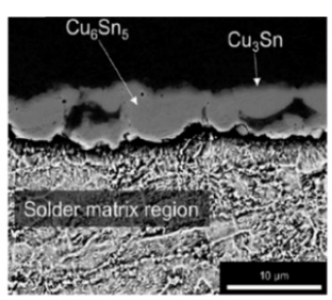

(b)
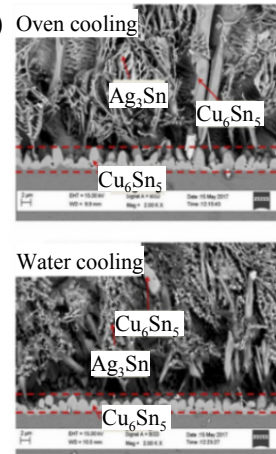
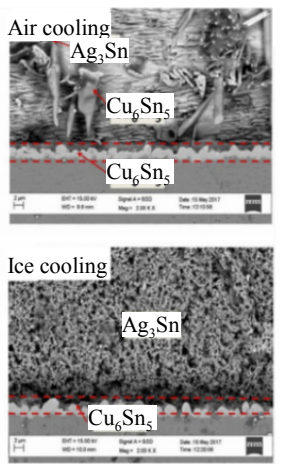
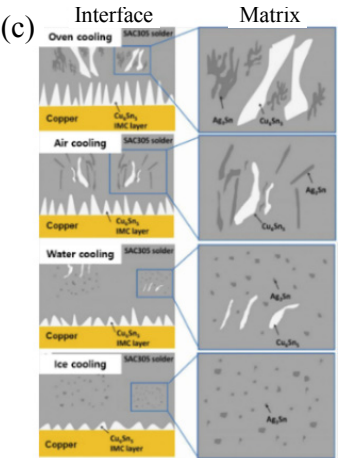

Fig. 18 Growth behavior of IMC in the interface between SAC305 solder and Cu substrate: (a) configuration of IMC lay$\mathrm{er}^{47)}$, (b) formation of microstructure by cooling methods ${ }^{48)}$, and (c) schematic diagram of microstructure ${ }^{48)}$ 
(a) As bonded

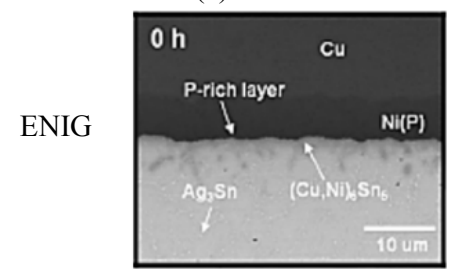

OSP

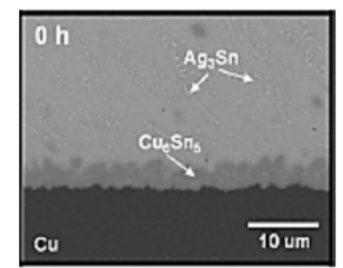

(b) Annealing
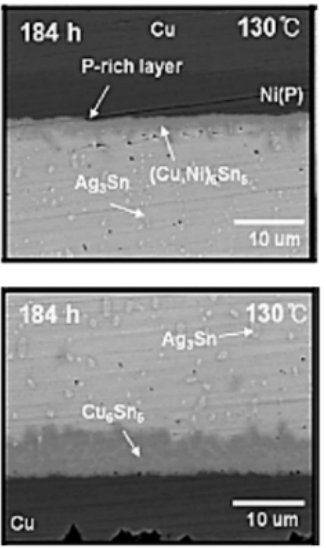

(c) e-downstream
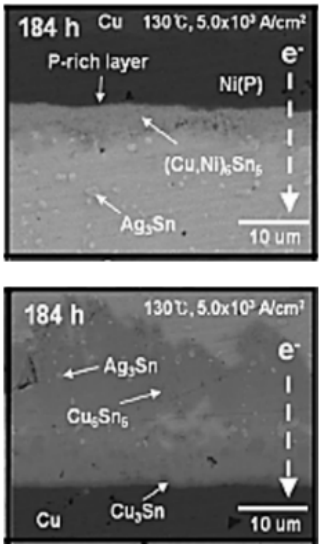

(d) e-upstream
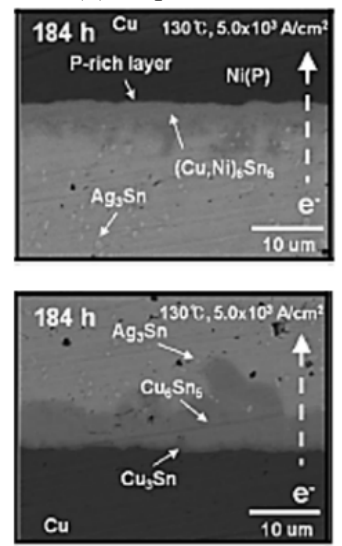

Fig. 19 SEM images of ENIG and OSP interfaces of cross-sectioned SAC305 solder ${ }^{49)}$ : (a) as-bonded, (b) annealing after $184 \mathrm{~h}$ at $130{ }^{\circ} \mathrm{C}$, (c) electron downstream and (d) upstream at $5.0 \times 10^{3} \mathrm{~A} / \mathrm{cm}^{2}$ for $184 \mathrm{~h}$

$\mathrm{Cu}_{6} \mathrm{Sn}_{5}$ and $\mathrm{Cu}_{6} \mathrm{Sn}_{5}$ in OSP grew thicker than $(\mathrm{Cu}, \mathrm{Ni})_{6} \mathrm{Sn}_{5}$ in ENIG under the heat treatment con dition of $130{ }^{\circ} \mathrm{C}$ for $184 \mathrm{~h}$, (Fig. 19b) due to rapid diffusion of $\mathrm{Cu}$ in a high-temperature atmosphere and rapid growth of the IMC phase of $\mathrm{Cu}_{6} \mathrm{Sn}_{5}$. IMC growth behavior according to the electron direction after $184 \mathrm{~h}$ of current stressing at a current density of $5.0 \times 103$ $\mathrm{A} / \mathrm{cm}^{2}$ at $130^{\circ} \mathrm{C}$ is as shown in Figs. $19 \mathrm{c}$ and $19 \mathrm{~d}$. The thickness of the IMC tended to be increased as the current was stressed, and thick $\mathrm{Cu}_{6} \mathrm{Sn}_{5}$ was observed in OSP although thin $(\mathrm{Cu}, \mathrm{Ni})_{6} \mathrm{Sn}_{5}$ IMC layer was formed in ENIG regardless of the electron direction. In the case of downstream electron, the $\mathrm{Cu}_{6} \mathrm{Sn}_{5}$ IMC layer was formed thicker by about twice that of the case of upstream electrons. This is because IMC is generated due to diffusion of solder and $\mathrm{Cu}$, and $\mathrm{Cu}$ in the solder is accumulated at the interface on the OSP side due to the electron direction in the case of downstream electrons. This IMC growth behavior is caused by the polarity effect due to $\mathrm{EM}^{50)}$. It also changes the difference in the diffusion degree of the type of surface finish. In the case of the ENIG surface finish, the plated $\mathrm{Ni}$ layer acts as a diffusion barrier layer for $\mathrm{Cu}$ to suppress the diffusion of $\mathrm{Cu}$. Therefore, IMC grew less than that of OSP surface finish in the case of ENIG surface finish.

There is a problem in general that the rapid formation of IMCs such as $\mathrm{Cu}_{6} \mathrm{Sn}_{5}$ and $\mathrm{Cu}_{3} \mathrm{Sn}$ due to the rapid reactivity with the solder reduces the reliability of the junction in the junction between the $\mathrm{Cu}$ substrate and the SAC305 ${ }^{49)}$. Ni plating technology, which acts as a diffusion barrier layer, is being applied in order to improve this problem, and Electroless Nickel Immersion Gold (ENIG) and Electroless Nickel Electroless Palladium Immersion Gold (ENEPIG) plating layer are mainly being used ${ }^{51,52)}$. This surface finish affects the reliability of the package, and furthermore, it has a substantial correlation with the lifespan of the package. Therefore, ENIG and ENEPIG surface finishes are used as UBM (under bump metallization) materials in the fine pitch flip chip process recently due to their good wettability and electroless plating characteristics, and outstanding diffusion barrier characteristics.

\subsection{Future trend of solder joint technology deve- lopment}

Since a bonding process such as soldering is performed on the PCB surface finish layer in the electronic packaging, the weldability and long-term reliability of the package itself are significantly affected by the surface finish characteristics. The surface finish method of the substrate rather than the type of solder has an important influence on EM since $\mathrm{Sn}$ is the main alloying element in various solder alloys. Although the representative surface finish methods include $\mathrm{Cu}$ OSP, hot air solder leveling (HASL), immersion tin, immersion silver, and ENIG and ENEPIG, the ENIG and ENEPIG surface finishes which are the electroless plating technologies, are mainly used rather than the surface finish in which the $\mathrm{Cu}$ substrate is directly exposed ${ }^{53,54)}$. In particular, it has been reported that the ENEPIG surface finish layer is better than ENIG in metallurgical and mechanical reliability. The reason is that it suppresses the formation of IMC and Kirkendall voids of $\mathrm{Ni}_{3} \mathrm{Sn}_{4}$ and $\mathrm{Ni}_{3} \mathrm{P}$ due to the Pd layer between the $\mathrm{Au}$ and $\mathrm{Ni}$ layers of the ENEPIG layer ${ }^{55}$. However, there is a problem that the gap between solders is decreased and the occurrence of defects due to the increased electrical resistance is increased in order to satisfy the accelerated fine pitch technology since the conventional 


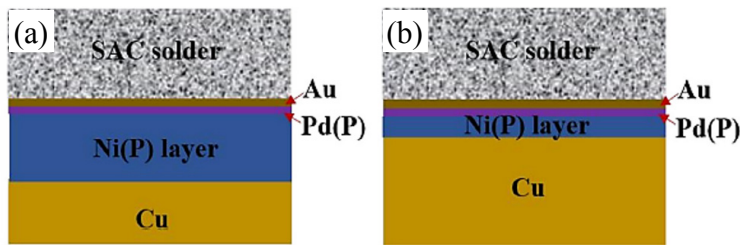

Fig. 20 Schematics of surface finishes: (a) normal- and (b) thin-ENEPIG

ENEPIG surface finish is thick with about 3-7 $\mu$ m-thick $\mathrm{Ni}^{56)}$. A thin surface finish technology with less than 1 $\mu \mathrm{m}$-thick $\mathrm{Ni}$ is being developed (Fig. 20) and various studies are being conducted in order to solve these shortcomings ${ }^{56,57)}$.

The thin ENEPIG surface finish has good applicability to fine pitch technology and can be applied not only to soldering but also to various bonding methods. In addition, it is expected to expand the scope of application for R\&D as it has good thermal resistance and plating adhesion, and furthermore, reduces the process price $^{58)}$. Many research institutes are currently conducting studies on the properties of solder joints with ENEPIG surface finish of less than $1 \mu \mathrm{m}$ applied, and commercialization is slow due to problems with reliability and lack of experience in the development field although advanced package manufacturers have entered the test stage for mass production applications.

In addition, the EM phenomenon at the $\mathrm{Pb}$-free solder junction has the closest relationship with the nucleation and growth rates of IMC and void. The stress-migration induced by TM effect and stress, and the warpage phenomenon caused by the stacking of packages in addition to the EM phenomenon need to be considered since the TM effect of increasing the temperature due to Joule heating in the solder joint is increased remarkably as the current density is increased. It is determined that the reliability for the life of the package can be further improved by considering the above.

\section{Conclusions}

There are challenges that must be overcome technologically with the advent of the next-generation packaging era beyond the current packaging technology. Although the defects due to EM phenomenon among them, which have the greatest effect on solder joints, have been reported so far, they are recognized as the most practical problems due to changes in requirements resulting from miniaturization and high density of packages. In summary, the following problems and improvements are presented.

1) The studies on EM phenomena in various solder joints are being conducted as solder became $\mathrm{Pb}$-free. It is determined that the application of $\mathrm{Pb}$-free solder has stronger resistance to $\mathrm{EM}$ phenomenon than $\mathrm{Sn}-\mathrm{Pb}$ solder according to the previously reported research data $^{61)}$. It is believed that the problem with the EM phenomenon can be solved once additional studies such as the nucleation and growth rate of IMC and void due to $\mathrm{EM}$ phenomenon in various $\mathrm{Pb}$-free solder joints, EM rate prediction due to variables such as current density and stressing time, and the effect of Sn growth direction on EM phenomenon are conducted.

2) Various study equipment have been used to conduct these studies, and analyses that applied the latest equipment such as analysis of IMC behavior over time through in-situ images and identification of mechanisms for IMC behavior through TEM analysis have been conducted recently, and these analyses can improve the reliability of study results on solder joints.

3) A number of studies have been conducted on various joints so far, and although solder/ENEPIG is known to have the best bonding characteristics when applying ENEPIG surface treatment substrates, research to reduce the Ni layer of ENEPIG to less than $1 \mu \mathrm{m}$ is being conducted to satisfy the accelerated micro-pitch technology. However, various research and development must be conducted since it is currently in the test phase for mass production application. Therefore, it is expected the development for solder joints will be intensively researched through the method of reducing the Ni layer of ENEPIG in the future.

4) In accordance with the era of the $4^{\text {th }}$ industrial revolution, modeling studies and warpage studies that can predict the experimental results of the growth of IMC layers and Kirkendall voids due to EM and TM at the interface between ENEPIG and solder are essential.

\section{Acknowledgment}

This work was supported by the Technology Innovation Program - Materials and Components Development Program (Grant No. 20011427) funded by the Korean Ministry of Trade, Industry, and Energy (MOTIE) and Competency Development Program for Industry Specialists of Korea Institute for Advancement of Technology (KIAT) (Grant No. P0002019) in the Republic Korea.

ORCID: Sujong Kim: http://orcid.org/0000-0002-1030-0942 ORCID: Wonsik Hong: http://orcid.org/0000-0001-8398-177X ORCID: Hyunbin Nam: http://orcid.org/0000-0003-3152-9567

ORCID: Namhyun Kang: http://orcid.org/0000-0002-9460-5128

\section{References}

1. M. Kim, Y. Ko, J. Bang and C. Lee, The Chip Bonding Technology on Flexible Substrate by Using Micro 
Lead-free Solder Bump, J. Microelectron. Packag. Soc. 19(3) (2012) 15-20.

http://dx.doi.org/10.6117/kmeps.2012.19.3.015

2. Y. K. Ko, Y. H. Ko and C. W. Lee, Micro-bump Joining Technology for 3 Dimensional Chip Stacking, $J$. Korean Soc. Precis. Eng. 31(10) (2014) 865-871. http://dx.doi.org/10.7736/KSPE.2014.31.10.865

3. G. Kim, K. Son, G. T. Park, Y. B. Park, Effect of Current Densities on the Electromigration Failure Mechanisms of Flip-Chip Sn-Ag Solder Bump, Korean J. Met. Mater. 55(11) (2017) 798-805.

https://doi.org/10.3365/KJMM.2017.55.11.798

4. J. M. Park, S. H. Kim, M. H. Jeong and Y. B. Park, Effect of $\mathrm{Cu}-\mathrm{Sn}$ intermetallic compound reactions on the Kirkendall void growth characteristics in $\mathrm{Cu} / \mathrm{Sn} / \mathrm{Cu}$ microbumps, Jpn. J. Appl. Phys. 53 (2014) 1-4.

5. G. Ross, V. Vuorinen and M. P-Krokel, Void formation and its impact on $\mathrm{Cu}-\mathrm{Sn}$ intermetallic compound formation, J. Alloy. Compd. 677 (2016) 127-138. https://doi.org/10.1016/j.jallcom.2016.03.193

6. J. H. Lee, N. H. Kang, C. W. Lee and J. H. Kim, Necessity of Low Melting Temperature $\mathrm{Pb}$-free Solder Alloy and Characteristics of Representative Alloys, $J$. Koran Weld. Join. Soc. 24(2) (2006) 17-28.

7. S. Jin, N. Kang, K. Cho, C. Lee and W. Hong, Behavior of Vibration Fracture for Sn-Ag-Cu-X Solders by Soldering, J. Koran Weld. Join. Soc. 30(2) (2012) 169173.

http://dx.doi.org/10.5781/KWJS.2012.30.2.169

8. C. Y. Kang, Research Trend in Development of $\mathrm{Pb}$ Free Solder, J. Koran Weld. Join. Soc. 13(4) (1995) 1-6.

9. W. Yang, R. W. Messler and L.E. Felton, Microstructure Evolution of Eutectic Sn-Ag Solder Joints, J. Electron. Mater. 23 (1994) 765-772.

https://doi.org/10.1007/BF02651371

10. Y. Wang, K. H. Lu, V. Gupta, L. Stiborek, D. Shirley, S. H. Chae, J. Im and P. S. Ho, Effects of Sn grain structure on the electromigration of $\mathrm{Sn}-\mathrm{Ag}$ solder joints, J. Mater. Res. 27(8) (2012) 1131-1141. https://doi.org/10.1557/jmr.2012.10

11. S. H. Kim, B. R. Lee, G. T. Park, J. M. Kim, S, H. Yoo and Y. B. Park, Effects of PCB surface finishes on the Mechanical and Electrical Reliabilities of $\mathrm{Sn}-0.7 \mathrm{Cu}$ Pb-free Solder Bump, J. Microelectron. Packag. Soc. 53(10) (2015) 735-744.

https://doi.org/10.6117/kmeps.2012.19.4.057

12. Y. Kim, J. Kwon, D. Yoo, S. Park, D. Lee and D. Lee, Influence of Nickel Thickness and Annealing Time on the Mechanical Properties of Intermetallic Compounds Formed between $\mathrm{Cu}-\mathrm{Sn}$ Solder and Substrate, Korean J. Met. Mater. 55(3) (2017) 165-172. https://doi.org/10.3365/KJMM.2017.55.3.165

13. S. K. Lim, Physical Design for 3D System on Package, IEEE Design and Test of Computers. 22(6) (2005) 532-539.
https://doi.org/10.1109/MDT.2005.149

14. M. Dong, F. Santagata, R. Sokolovskij, J. Wei, C. Yuan and G, Zhang, 3D system-in-package design using stacked silicon submount technology, Microelectron. Int. 32(2) (2015) 63-72.

https://doi.org/10.1108/MI.11.2014.0050

15. J. H. Lan, Evolution and Outlook of TSV and 3D IC/Si Integration, $201012^{\text {th }}$ Electronics Packaging Technology Conference, Singapore (2010) https://doi.org/10.1109/EPTC.2010.5702702

16. B. H. L. Chao, X. Zhang, S. H. Chae, P. S. Ho, Recent advances on kinetic analysis of electromigration enhanced intermetallic growth and damage formation in $\mathrm{Pb}$-free solder joints, Microelectron. Reliab. 49(3) (2009) 253-263. https://doi.org/10.1016/j.microrel.2009.01.006

17. S. Baek, Y. Park, C. Oh, E. Chun and N. Kang, Modeling and Experimental Verification of Intermetallic Compounds Grown by Electromigration and Thermomigration for Sn-0.7Cu Solders, J. Electron. Mater. 48(1) (2019) 142-151. https://doi.org/10.1007/s11664-018-6786-4

18. S. Li, X. Wang, Z. Liu, Y. Jin, S. Zhang, J. Geng, X. Chen, S. Wu, P. He and W. Long, Corrosion behavior of $\mathrm{Sn}$ based lead free solder alloys: a review, J. Mater. Sci. 31 (2020) 9076-9090. https://doi.org/10.1007/s10854-020-03540-2

19. P. Zhang, S. Xue, J. Wang, P. Xue, S. Zhong and W. Long, Effect of Nanoparticles Addition on the Microstructure and Properties of Lead-Free Solders: A Review, Appl. Sci. 9(10) (2019) 1-20. https://doi.org/10.3390/app9102044

20. J. Lee, K. Kim and S. Huh, Development of Sn-Zn Based Low Temperature Lead-Free Solder for Improvement of Oxidation Resistance, J. Korean Weld. Join. Soc. 29(5) (2011) 514-521.

http://dx.doi.org/10.5781/KWJS.2011.29.5.514

21. J. Lee, K. Kim, M. Inoue, J. Jiang and K. Suganuma, Effects of $\mathrm{Ag}$ and $\mathrm{Cu}$ addition on microstructural properties and oxidation resistance of $\mathrm{Sn}-\mathrm{Zn}$ eutectic alloy, J. Alloy. Compd. 454 (2008) 310-320. https://doi.org/10.1016/j.jallcom.2006.12.037

22. R. Darveaux and K. Banerji, Constitutive Relations for Tin-Based-Solder Joints, IEEE Trans. Compon. Hybirds. Manuf. Technol. 15(6) (1992) 1013-1024. https://doi.org/10.1109/33.206925

23. I. Artaki, A. M. Jackson and P. T. Vianco, Evaluation of Lead-Free Solder Joints in Electronic Assemblies, J. Electron. Mater. 23(8) (1994) 757-764. https://doi.org/10.1007/BF02651370

24. J. Y. Park, J. P. Jung and C. S. Kang, The Analysis of the Withdrawal Force Curve of the Wetting Balance Curve, IEEE Trans. Compon. Hybirds. Manuf. Technol. 22(3) (1999) 372-377. https://doi.org/10.1109/6144.796538 
25. M. Kim, K. Shin and J. Jung, Research Trends of SnAg Based Pb-Free Solders, J. Weld. Join. 19(1) (2001) $15-20$.

26. P. T. Vianco and J. A. Rejent, Properties of Ternary Sn-Ag-Bi Solder Alloys: Part II-Wettability and Mechanical Properties Analyses, J. Electron. Mater. 28(10) (1999) 1138-1143. https://doi.org/10.1007/s11664-999-0251-3

27. J. Lee, H. Kim, Y. Lee and Y. Choi, Interfacial Properties with Kind of Surface Finish and Sn-Ag Based Lead-free Solder, J. Korean Weld. Join. Soc. 27(1) (2009) 20-24. https://doi.org/10.5781/KWJS.2009.27.1.020

28. K. Lee, K. Kim and K. Suganuma, Electro-migration Phenomenon in Flip-chip Packages, J. Microelectron. Packag. Soc. 17(4) (2010) 11-17.

29. R. A. Islam, B. Y. Wu, M. O. Alam, Y. C. Chan and W. Jillek, Investigations on microhardness of Sn-Zn based lead-free solder alloys as replacement of $\mathrm{Sn}-\mathrm{Pb}$ solder, J. Alloy. Compd. 392 (2005) 149-158. https://doi.org/10.1016/j.jallcom.2004.08.079

30. M. Date, T. Shoji, M. Fujiyoshi, K. Sato and K. N. Tu, Ductile-to-brittle transition in $\mathrm{Sn}-\mathrm{Zn}$ solder joints measured by impact test, Scr. Mater. 51 (2004) 641645. https://doi.org/10.1016/j.scriptamat.2004.06.027

31. P. Xue, S. Xue, Y. Shen and H. Zhu, Interfacial microstructures and mechanical properties of $\mathrm{Sn}-9 \mathrm{Zn}-0.5 \mathrm{Ga}-$ $\mathrm{xNd}$ on $\mathrm{Cu}$ substrate with aging treatment, Mater. Des. 60 (2014) 1-6.

http://dx.doi.org/10.1016/j.matdes.2014.03.052

32. R. S. Lai, K. L. Lin and B. Salam, Suppressing Growth of the $\mathrm{Cu} 5 \mathrm{Zn} 8$ Intermetallic Layer in $\mathrm{Sn}-\mathrm{Zn}-\mathrm{Ag}$ $\mathrm{Al}-\mathrm{Ga} / \mathrm{Cu}$ Solder Joints, J. Electron. Mater. 38(1) (2009) 88-92. https://doi.org/10.1007/s11664-008-0579-0

33. X. F. Zhang and J. D. Guo, Reverse polarity effect from effective charge disparity during electromigration in eutectic $\mathrm{Sn}-\mathrm{Zn}$ solder interconnect, J. Mater. Res. 23(12) (2008) 3370-3378. https://doi.org/10.1557/JMR.2008.0413

34. M. L. Huang, Q. Zhou, N. Zhao, X. Y. Lin and Z. J. Zhang, Reverse polarity effect and cross-solder interaction in $\mathrm{Cu} / \mathrm{Sn}-9 \mathrm{Zn} / \mathrm{Ni}$ interconnect during liquid-solid electromigration, J. Mater. Sci. 49 (2014) 17551763. https://doi.org/10.1007/s10853-013-7862-Z

35. M. Huang, Z. Zhang, N. Zhao and X. Feng, Reverse Polarity Effect in $\mathrm{Cu} / \mathrm{Sn}-9 \mathrm{Zn} / \mathrm{Ni}$ Interconnect under High Current Density at High Temperature, 2014 15th International Conference on Electronic Packaging Technology, Chengdu China (2014) https://doi.org/10.1109/ICEPT.2014.6922690

36. M. L. Huang, Z. J. Zhang, N. Zhao and Q. Zhou, A synchrotron radiation real-time in situ imaging study on the reverse polarity effect in $\mathrm{Cu} / \mathrm{Sn}-9 \mathrm{Zn} / \mathrm{Cu}$ interconnect during liquid-solid electromigration, $S c r$.
Mater. 68 (2013) 853-856.

http://dx.doi.org/10.1016/j.scriptamat.2013.02.007

37. S. Kuo and K. Lin, Polarity effect of electromigration on intermetallic compound formation in a $\mathrm{Cu} / \mathrm{Sn}-9 \mathrm{Zn} /$ Cu sandwich, J. Mater. Res. 23(4) (2008) 1087-1 094. https://doi.org/10.1557/jmr.2008.0142

38. M. Zhao, L. Zhang, Z. Lin, M. Xiong and L. Sun, Structure and properties of $\mathrm{Sn}-\mathrm{Cu}$ lead-free solders in electronics packaging, Sci. Technol. Adv. Mater. 29 (2019) 421-444. https://doi.org/10.1080/14686996.2019.1591168

39. F. Hung, T. Lui, L. Chen and N. He, Resonant characteristics of the microelectronic $\mathrm{Sn}-\mathrm{Cu}$ solder, J. Alloy Compd. 457 (2008) 171-176. https://doi.org/10.1016/j.jallcom.2007.03.026

40. L. Yang, Y. Zhang, J. Dai, Y. Jing, J. Ge and N. Zhang, Microstructure, interfacial IMC and mechanical properties of Sn-0.7Cu- $x \mathrm{Al}(x=0-0.075)$ lead-free solder alloy, Mater. Des. 67 (2015) 209-216.

http://dx.doi.org/10.1016/j.matdes.2014.11.036

41. A. A. El-Daly and A. E. Hammad, Enhancement of creep resistance and thermal behavior of eutectic $\mathrm{Sn}-\mathrm{Cu}$ lead-free solder alloy by $\mathrm{Ag}$ and In-additions, Mater. Des. 40 (2012) 292-298. http://dx.doi.org/10.1016/j.matdes.2012.04.007

42. M. Heo, N. Kang, S. Park, J. Kim and W. S. Hong, Kinetics of Intermetallic Compounds Growth Induced by Electromigration of $\mathrm{Sn}-0.7 \mathrm{Cu}$ Solder, Korean J. Met. Mater. 54(12) (2016) 908-915. https://doi.org/10.3365/KJMM.2016.54.12.908

43. H. Lee, Y. Chen, Evolution of Ag3Sn intermetallic compounds during solidification of eutectic $\mathrm{Sn}-3.5 \mathrm{Ag}$ solder, J. Alloy. Compd. 509 (2011) 2510-2517. https://doi.org/10.1016/j.jallcom.2010.11.068

44. B. Guo, A. Kunwar, N. Zhao, J. Chen, Y. Wang, H. Ma, Effect of $\mathrm{Ag} 3 \mathrm{Sn}$ nanoparticles and temperature on $\mathrm{Cu}_{6} \mathrm{Sn}_{5}$ IMC growth in $\mathrm{Sn} x \mathrm{Ag} / \mathrm{Cu}$ solder joints, Mater. Res. Bull. 99 (2018) 239-248. https://doi.org/10.1016/j.materresbull.2017.11.022

45. Y. Jung and J. Yu, Electromigration induced Kirkendall void growth in $\mathrm{Sn}-3.5 \mathrm{Ag} / \mathrm{Cu}$ solder joints, J. Appl. Phys. 115 (2014) 083708:1-9. https://doi.org/10.1063/1.4867115

46. Y. Park, J. Bang, C. M. Oh, W. S. Hong and N. Kang, The Effect of Eutectic Structure on the Creep Properties of $\mathrm{Sn}-3.0 \mathrm{Ag}-0.5 \mathrm{Cu}$ and $\mathrm{Sn}-8.0 \mathrm{Sb}-3.0 \mathrm{Ag}$ Solders, Met. 7(12) (2017) 540:1-12. https://doi.org/10.3390/met7120540

47. A. T. Tan, A. W. Tan and F. Yusof, Evolution of microstructure and mechanical properties of $\mathrm{Cu} / \mathrm{SAC} 305 / \mathrm{Cu}$ solder joints under the influence of low ultrasonic power, J. Alloy. Compd. 705 (2017) 188-197. http://dx.doi.org/10.1016/j.jallcom.2017.02.165

48. M. Z. Yahaya, N. A. Salleh, S. Kheawhom, B. Illes, M. F. M. Nazeri and A. A. Mohamad, Selective etching and hardness properties of quenched SAC305 solder 
joints, Solder. Surf. Mount Technol. 32(4) (2020) 225233. https://doi.org/10.1108/SSMT-01-2020-0001

49. S. Kim, G. Park, B. Lee, J. Kim, S. Yoo and Y. Park, Effects of PCB Surface Finishes on in-situ Intermetallics Growth and Electromigration Characteristics of Sn-3.0Ag-0.5Cu Pb-free Solder Joints, J. Microelectron. Packag. Soc. 22(2) (2015) 47-53.

http://dx.doi.org/10.6117/kmeps.2015.22.2.047

50. J. Choi, S. Jun, H. Won, B. Jung and T. Oh, Electromigration Behavior of Flip-Chip Bonded Sn-3.5Ag0.5Cu Solder Bumps, J. Microelectron. Packag. Soc. 11(4) (2004) 43-48.

51. K. Kim, W. Seo, S. Kwon, J. Kim, J. Yoon and S. Yoo, Effects of Ni-P Bath on the Brittle Fracture of Sn-Ag-Cu Solder/ENEPIG Solder Joint, J. Weld. Join. 35(3) (2017) 1-6. https://doi.org/10.5781/JWJ.2017.35.3.1

52. S. Huh, J. Lee and S. Ham, Reliability of Sn-Ag-Cu Solder Joint on ENEPIG Surface Finish: 1. Effects of thickness and roughness of electroless Ni-P deposit, $J$. Microelectron. Packag. Soc. 21(3) (2014) 43-50. http://dx.doi.org/10.6117/kmeps.2014.21.3.043

53. J. Yoon, B. Noh and S. Jung, Comparative Study of ENIG and ENEPIG as Surface Finishes for a $\mathrm{Sn}-\mathrm{Ag}-\mathrm{Cu}$ Solder Joint, J. Electron. Mater. 40(9) (2011) 1950-1955. https://doi.org/10.1007/s11664-011-1686-x
54. J. Yoon, J. Bang, C. Lee and S. Jung, Interfacial reaction and intermetallic compound formation of Sn-1Ag/ENIG and $\mathrm{Sn}-1 \mathrm{Ag} / \mathrm{ENEPIG}$ solder joints, J. Alloy. Compd. 627 (2015) 276-280. http://dx.doi.org/10.1016/j.jallcom.2014.11.208

55. C. Ho and J. Duh, Quantifying the dependence of Ni(P) thickness in ultrathin-ENEPIG metallization on the growth of $\mathrm{Cu}-\mathrm{Sn}$ intermetallic compounds in soldering reaction, Mater. Chem. Phys. 148 (2014) 21-27. http://dx.doi.org/10.1016/j.matchemphys.2014.06.072

56. J. Back, S. Yoo, D. Han, S. Jung and J. Yoon, Interfacial Reactions and Mechanical Strength of Sn-3.0Ag$0.5 \mathrm{Cu} / 0.1 \mu \mathrm{m}-\mathrm{Ni}$ Thin ENEPIG Solder Joints, J. Weld. Join. 35(6) (2017) 51-58. https://doi.org/10.5781/JWJ.2017.35.6.8

57. J. Kim, S. Jung and J. Yoon, Effect of Ni(P) thickness in $\mathrm{Au} / \mathrm{Pd} / \mathrm{Ni}(\mathrm{P})$ surface finish on the electrical reliability of $\mathrm{Sn}-3.0 \mathrm{Ag}-0.5 \mathrm{Cu}$ solder joints during current-stressing, J. Alloy. Compd. 850 (2021) 156729: $1-11$. https://doi.org/10.1016/j.jallcom.2020.156729

58. J. Back, B. Lee, S. Yoo, D. Han, S. Jung and J. Yoon, Solderability of thin ENEPIG plating Layer for Fine Pitch Package application, J. Microelectron. Packag. Soc. 24(1) (2017) 83-90.

https://doi.org/10.6117/kmeps.2017.24.1.083 


\title{
Electromigration에 의한 다양한 솔더 접합부에서의 금속간 화합물 성장거동

\author{
Growth Behavior of Intermetallic Compounds \\ in Various Solder Joints Induced by Electromigration
}

\author{
김수종* · 홍원식** - 남현빈 ${ }^{*}$ - 강남현* \\ *부산대학교 재료공학과 \\ **한국전자기술연구원 융복합전자소재연구센터
}

\section{1. 서 론}

최근 전자산업은 스마트폰, $3 \mathrm{D} \mathrm{TV}$ 및 컴퓨터 등과 같은 주요 제품의 소형화 및 고성능화에 대한 요구가 증대하고, 이러한 요구를 만족시키기 위하여 칩과 메인 보드를 연결시켜주는 $\mathrm{PCB}$ (Printed Circuit Board) 기판 내 많은 소자 및 단자를 실장하기 위한 미세피치 구현기술이 지속적으로 개발되고 있다 ${ }^{1,2)}$. 미세피치 기 술개발과 함께 칩과 기판을 연결시켜주는 솔더범프가 미세화 되면서 이에 인가되는 전류밀도가 급격히 증가되 는 문제가 발생되었다. 이러한 전류밀도 및 joule heating 에 의한 온도 증가로 솔더범프에 electromigration (EM) 및 thermo-migration(TM)에 의한 2차상의 생성 및 성장이 발생하며, 이 현상이 패키지에서 전기적 단선 및 전 기저항이 급격히 증가되어 단전(Open-Circuit Failure) 되는 심각한 문제까지 야기된다 ${ }^{3)}$. 발생된 문제점의 주 원인인 솔더와 기판 사이에 형성되는 금속간 화합물 (Intermetallic Compound, IMC)과 Kirkendall voids 의 형성 및 성장은 electromigration (EM)에 의하여 가속화된다고 알려져 있다 ${ }^{4,5)}$.

$\mathrm{Pb}-\mathrm{Sn}$ 계 합금은 전자기기의 솔더범프에 주로 적용 되던 합금으로 2006년까지 활발히 사용되어져 왔다. 하지만 납중독 문제가 대두되면서 무연 $(\mathrm{Pb}-\mathrm{free})$ 솔더 에 대한 연구가 지속적으로 진행되어 다양한 합금의 솔 더가 개발되어 있다 ${ }^{6-8)}$. 현재까지는 $\mathrm{Sn}-\mathrm{Ag}$ 계 합금 솔 더 범퍼에서의 금속간 화합물 및 Kirkendall void 성 장거동과 관련된 연구가 주로 이루어져 왔으남,10), 최 근에는 $\mathrm{Sn}-\mathrm{Cu}$ 계 합금의 솔더범프 접합부에서의 $\mathrm{EM}$ 효과에 대한 연구도 진행되었다 ${ }^{11,12)}$.

Fig. 1은 Package on Package (PoP) 및 3D System in Package $(\mathrm{SiP})$ 기술 등이 적용되면서 초 소형화된

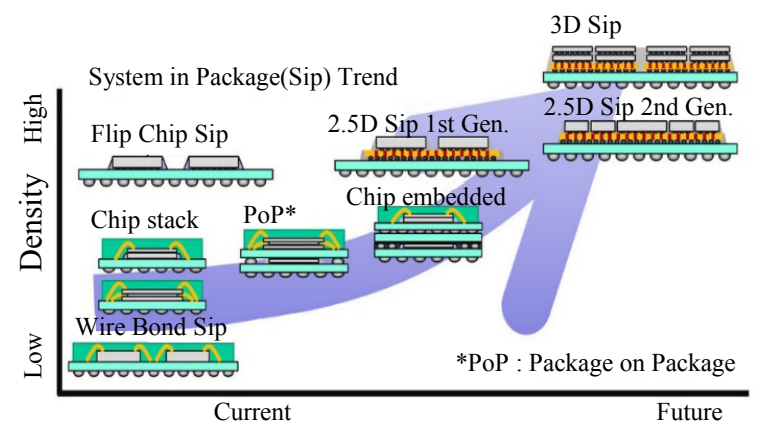

Fig. 1 Development trend of electronic packages ${ }^{15}$

미세피치 기술에 의해 패키지 내에 실장되는 부품의 증 가 및 소형화 추세를 나타낸다 ${ }^{13-15)}$. 소형화에 따라 솔 더범프에 인가되는 전류밀도는 급격히 증가하고 있기 때문에 결함 발생의 효율적인 방안을 위하여 패키지의 구조적 변화 및 솔더범프 재질의 변화가 이루어져야 할 것으로 판단된다. 따라서, 본 논문에서는 다양한 재질 의 솔더범프 접합부에서 $\mathrm{EM}$ 효과에 따른 접합부 IMC 및 voids 변화를 정리하고, $\mathrm{EM}$ 에 따른 $\mathrm{IMC}$ 의 변화 를 예측하는 연구를 소개한다.

\section{Electromigration 실험과 모델링 방법}

$\mathrm{EM}$ 에 의한 $\mathrm{IMC}$ 의 성장은 금속 배선에 전류가 인가 되었을 때 이동하는 전자가 금속 원자와 충돌하면서 생 기는 운동량 교환에 의해서 전자의 이동 방향으로 금속 원자가 이동하게 되면서 발생하게 된다. 이 때 $\mathrm{EM}$ 에 의한 금속원자 이동의 구동력으로는 전자풍력(electron wind force)와 정전기력(electrostatic force)이 있 다. 전자풍력은 전기장에 의해 가속된 전자들이 금속원 자와 충돌하여 금속원자에 운동량을 전달하면서 움직이 게 하는 힘을 말하며, 정전기력은 가전자를 잃고 이온 으로 남아있는 원자에 작용하는 힘을 말한다. 따라서 
$\mathrm{EM}$ 에서의 유효 구동력은 아래 식 (1)과 같다 ${ }^{16)}$.

$$
J=\frac{C D}{k T} Z^{*} e \rho j
$$

J는 EM flux, C는 농도(concentration), $\mathrm{D}$ 는 확 산계수(diffusivity), $Z^{*}$ 는 유효전하수(effective charge number), $\mathrm{k}$ 는 볼츠만 상수, $\mathrm{T}$ 는 절대온도, $\mathrm{e}$ 는 전하 량, $\rho$ 는 비저항, $j$ 는 전류밀도이다.

또한 실제로 금속원자의 농도는 시간에 따라 변화한 다. 시간에 따른 농도 변화는 Fick's second law에 의 해 나타내어 진다 ${ }^{16)}$.

$$
\frac{\partial \mathrm{C}}{\partial \mathrm{t}}=-\frac{\partial \mathrm{J}}{\partial \mathrm{x}}
$$

식 (1)과 (2)를 통해 금속 원자, 솔더, 그리고 형성 되는 $\mathrm{IMC}$ 에서의 $\mathrm{EM}$ flux를 계산하여 전류 인가 시간 에 따라 성장하는 $\mathrm{IMC}$ 의 두께를 예측할 수 있다. $\mathrm{IMC}$ 의 성장은 Kirkendall voids의 형성 및 성장과 연관되어 있으므로, $\mathrm{IMC}$ 의 성장 예측 모델링을 통해 voids로 인한 전기저항 증가와 전기적 단선을 간접적 으로 예측한다. 예측한 $\mathrm{IMC}$ 의 두께가 실제 전류 인가 시 동일한 결과가 나오는지 검증을 하기 위해서는 실험 적 검증이 반드시 필요하다. Fig. $2 \mathrm{a}$ 는 $\mathrm{EM}$ 실험을 위 한 전류 인가 모식도를 나타내고, Fig. $2 \mathrm{~b}$ 는 TM 실험 을 위한 온도 구배 적용 모식도를 나타낸다. Fig. 2에 서 사용된 솔더합금은 $\mathrm{Sn}-0.7 \mathrm{Cu}$ 이고, 전원공급장치로 는 ITECH 사의 DC source meter(IT6153)를 사용

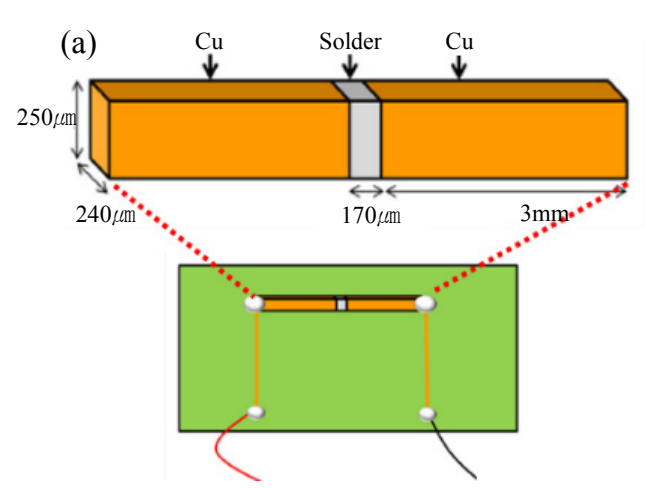

(b)

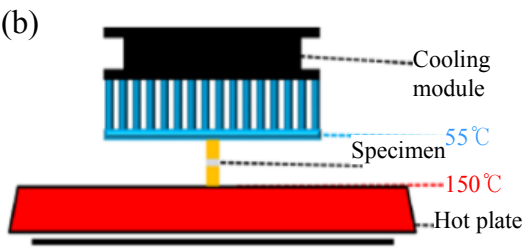

Fig. 2 Schematics diagram of (a) current stressing method for the EM experiments and (b) the TM experiments $^{17)}$
하였다. Fig. 2a와 같이 EM 실험 세트를 구축한 후 전원공급장치를 통해 일정 시간동안 전류를 인가하여 $\mathrm{IMC}$ 를 성장시킨다. 그 후 실제 측정한 $\mathrm{IMC}$ 의 두께와 모델링을 통해 계산된 $\mathrm{IMC}$ 의 두께를 비교하여 실험적 으로 검증된 모델링 결과를 내었다.

\section{3. 결과 및 고찰}

\section{1 무연 솔더 합금의 선택}

무연솔더 합금 선정 시 고려사항으로 $\mathrm{Sn}-\mathrm{Pb}$ 계 솔더 와 유사한 융점(melting point: $\sim 183{ }^{\circ} \mathrm{C}$ )을 가지며, 양호한 전기적 및 기계적 특성을 가지는 친환경 무연솔 더 합금의 적용이 요구된다. 현재 $\mathrm{Sn}-\mathrm{Pb}$ 계를 대체할 수 있는 $\mathrm{Sn}$ 계 기반의 다양한 솔더가 시판 중이며, 가 장 일반적인 무연솔더는 $\mathrm{Sn}-\mathrm{Ag}-\mathrm{Cu}, \mathrm{Sn}-\mathrm{Ag}, \mathrm{Sn}-\mathrm{Cu}$, $\mathrm{Sn}-\mathrm{Zn}, \mathrm{Sn}-\mathrm{Bi}$ 계 등이 있다 ${ }^{18)}$. 대부분의 무연솔더 합 금은 $\mathrm{Sn}$ 이 주성분으로 이루어지며, 미량의 $\mathrm{Ag}, \mathrm{Cu}$, $\mathrm{Zn}$, In 그리고 $\mathrm{Bi}$ 등의 성분으로 이루어진다 ${ }^{19)}$.

$\mathrm{Sn}-\mathrm{Zn}$ 계 공정조성의 솔더의 공정점은 $199{ }^{\circ} \mathrm{C}$ 로 융 점이 종래의 $\mathrm{Sn}-\mathrm{Pb}$ 솔더와 유사하여 기존의 프로세서 를 그대로 적용할 수 있다는 장점을 가지며, 높은 강도 와 크리프 특성 및 내열피로성이 우수하다. 하지만 산 소와의 반응성(reactivity)이 빠르고 기판과의 젖음성 (wettability)이 불량하므로 상용화에 제한적이다 ${ }^{20)}$. $\mathrm{Sn}-\mathrm{Zn}$ 공정합금에 $\mathrm{Bi}$ 를 소량 첨가시키면 젖음성의 향 상은 가능하나 산화가 가속화되는 단점이 발생되므로 미량의 $\mathrm{Ag}$ 와 $\mathrm{Cu}$ 첨가를 통하여 내산화성을 개선시킬 수 있다고 보고된다 ${ }^{21)}$.

$\mathrm{Sn}-\mathrm{Cu}$ 계 솔더의 공정 조성은 $\mathrm{Sn}-0.7 \mathrm{Cu}$ 이며, 공정 점은 $227{ }^{\circ} \mathrm{C}$ 이다. $\mathrm{Sn}-0.7 \mathrm{Cu}$ 솔더는 $\mathrm{Sn}-\mathrm{Ag}$ 합금에 비해 크립 (creep)강도가 낮으므로 피로특성에 의하여 솔더의 변형이 일어나며, 전자패키지에서 칩과 기판 간 의 열팽창 계수 차이에 의한 평탄도(warpage) 불량에 따른 솔더의 변형이 크랙(crack) 저항성이 우수하다고 보고되어 있으므로 최근 연구 및 사용이 증가되고 있다 ${ }^{22)}$.

$\mathrm{Sn}-\mathrm{Ag}$ 계 솔더의 공정조성은 $\mathrm{Sn}-3.5 \mathrm{Ag}$ 이며, 공정점 은 $221{ }^{\circ} \mathrm{C}$ 이다. $\mathrm{Sn}-\mathrm{Ag}$ 솔더의 적용온도 증가는 표면 장력 및 접촉각을 감소시키는 경향이 있다. $\mathrm{Sn}-\mathrm{Ag}$ 솔 더의 표면장력이 $\mathrm{Sn}-\mathrm{Pb}$ 에 비해 높으며, 접촉각 또한 높은 결과를 보이므로 ${ }^{23)} \mathrm{Sn}-\mathrm{Ag}$ 솔더가 $\mathrm{Sn}-\mathrm{Pb}$ 솔더에 비해 젖음 특성이 떨어진다고 보고된다 ${ }^{24)}$. 이러한 점을 보완하기 위하여 $\mathrm{Sn}-\mathrm{Ag}$ 에 미량의 $\mathrm{Cu}$ 를 첨가하면 젖 음 및 피로특성을 개선시킬 수 있으며, 미량의 $\mathrm{Bi}$ 첨가 시 젖음성이 개선되는 것으로 알려져 있다 ${ }^{25,26)}$.

현재 솔더링에서는 $\mathrm{Sn}-\mathrm{Ag}-\mathrm{Cu}$ 계 솔더가 주로 적용 
되는데, $\mathrm{Ag}$ 의 함유량이 증가되면 $\mathrm{Ag}_{3} \mathrm{Sn}$ 상이 조대하 게 생성되어 결함의 생성 및 전파 사이트가 될 수 있 다. 그러므로 $217{ }^{\circ} \mathrm{C}$ 융점의 $\mathrm{Sn}-3.0 \mathrm{Ag}-0.5 \mathrm{Cu}$ 솔더 가 $\mathrm{Sn}-\mathrm{Pb}$ 계를 대체할 수 있는 대표적인 솔더로 자리 잡고 있다 ${ }^{27)}$.

\section{2 솔더 접합부 내 $\mathrm{EM}$ 현상의 원인과 특성}

일반적으로 솔더 접합부에 전류를 인가하면, 온도상 승으로 인해 솔더 내의 금속원자가 전자의 이동방향을 따라 강한 흐름을 가지게 되며 이러한 원자의 흐름이 구동력이 되어 동일한 방향으로 원자의 이동이 활성화 되면서, anode 측의 $\mathrm{IMC}$ 가 급속하게 성장된다. 이와 반대로 공공 주위의 원자는 상대적으로 확산속도가 감 소하므로 cathode 측에 집적되어 void가 형성되고, 그 void의 성장 및 크랙(cracks) 생성으로 인한 단선 결 함에 이른다. 이는 $\mathrm{EM}$ 현상으로 발생되는 문제점이며, $\mathrm{EM}$ 현상에 대한 개략도를 Fig. 3에 나타낸다 ${ }^{28)}$. 또 한, 접합부 내의 joule heating 효과로 인하여 내부 온도가 $100{ }^{\circ} \mathrm{C}$ 이상으로 상승되며, 솔더 접합부가 가 지는 구조적 문제점으로 인하여 생성되는 전류과밀 현 상 때문에 $\mathrm{EM}$ 에 의한 열화 현상이 가속화된다. 그러 므로 솔더 접합부의 수명에 대한 신뢰성은 예측하기 힘

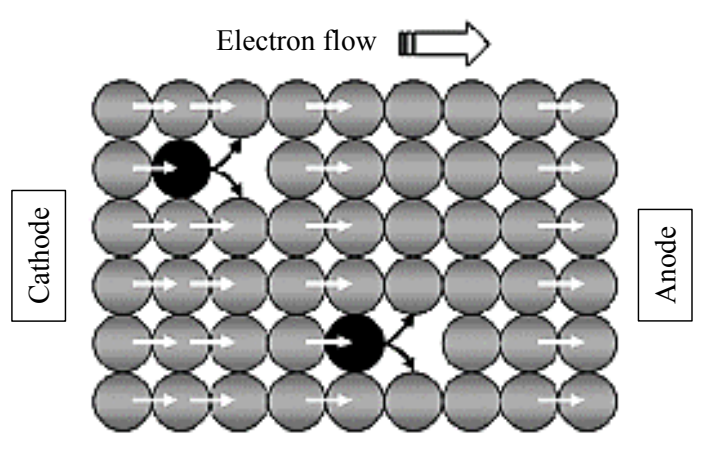

Fig. 3 Schematic illustration of elecromigration phenomena $^{28)}$
든 실정이며, 접합부 수명 향상을 위한 많은 연구가 진 행 중이다. $\mathrm{EM}$ 현상이 각 솔더 접합부에 미치는 영향 을 다룬 연구들은 Table 1에 정리하였다. EM에 따른 솔더 재질별 접합부의 $\mathrm{IMC}$ 생성 거동은 다음 절부터 설명한다.

\subsection{1 $\mathrm{Sn}-\mathrm{Zn}$ 계 솔더 접합부 특성}

Fig. 4는 $\mathrm{Sn}-9 \mathrm{Zn}$ 합금의 미세조직을 나타낸다. $\mathrm{Sn}^{-}$ $9 \mathrm{wt} \% \mathrm{Zn}$ 공정조성의 as-cast 솔더는 금속간 화합물을 형성하지 않았고(Fig. $4 \mathrm{a}$ ), 이 합금계의 미세조직은 침 상(needle-like shape) 의 $a-Z n$ 이 $\beta-\mathrm{Sn}$ 상의 기지 내에 미세하게 분산된 구조를 가진다 ${ }^{29,30)}$. 또한, Fig. $4 \mathrm{~b}$ 는 $\mathrm{Sn}-\mathrm{Zn}$ 솔더에서 $\mathrm{Zn}$-rich phase가 증가하면 $\mathrm{Zn}$ 원소가 산소와의 고반응성에 의해 $\mathrm{ZnO}$ 가 생성되므 로 내산화성을 크게 저하됨을 나타낸다 ${ }^{19}$. $\mathrm{Sn}-\mathrm{Zn}$ 솔 더의 접합특성을 향상시키기 위해서는 $\mathrm{ZnO}$ 의 형성을 조절하는 방안이 필요하다.

$\mathrm{Xue}^{31)}$ 의 연구에서는 energy-dispersive spectroscopy (EDS) line/spot 분석을 통하여 $\mathrm{IMC}$ 의 성장 및 성분 거동을 관찰하였고, $\mathrm{Guo}^{32}$ 는 $\mathrm{Sn}-\mathrm{Zn}$ 솔더의 내산화성 향상을 위한 방안으로 $\mathrm{Ag}$ 를 첨가하여 솔더 $/ \mathrm{Cu}$ 기판 계면의 IMC 거동을 분석하였다. Figs. $5 \mathrm{a}$ 와 $5 \mathrm{~b}$ 는 $\mathrm{Sn}-9 \mathrm{Zn}$ 솔더와 $\mathrm{Cu}$ 기판 $(\mathrm{Sn}-9 \mathrm{Zn} / \mathrm{Cu})$ 간의 $\mathrm{IMC}$ 층의 성분과 $\mathrm{Ag}$ 함유량 및 aging 시간 증 가에 따른 $\mathrm{IMC}$ 의 성장 거동을 각각 나타낸다. $\mathrm{Sn}^{-}$ $9 \mathrm{Zn}$ 솔더와 $\mathrm{Cu}$ 기판 간의 $\mathrm{IMC}$ 층은 주로 $\mathrm{CuZn}_{5}$ 와 $\mathrm{Cu}_{5} \mathrm{Zn}_{8}$ 으로 구성되며(Fig. $5 \mathrm{a}$ ), EDS 선분석을 통하
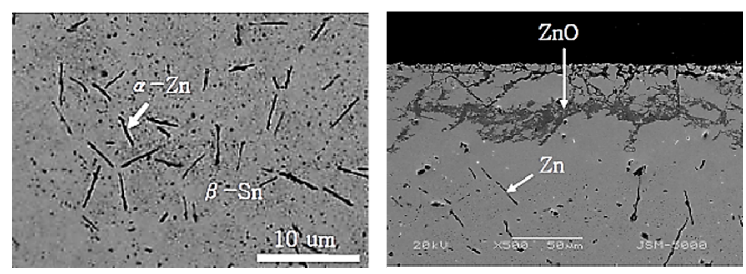

Fig. 4 Microstructure of Sn-9Zn alloy20): (a) the shape of each phase, (b) the formation of $\mathrm{ZnO}$

Table 1 Previous studies on EM for various solder joints

\begin{tabular}{|l|l|l|l|}
\hline Solder & Surface-finished & IMC & EM properies \\
\hline Sn-9Zn & $\mathrm{Cu}$ OSP & $\mathrm{Cu}_{5} \mathrm{Zn}_{8} / \mathrm{Cu}_{6} \mathrm{Sn}_{5}$ & $\begin{array}{l}\text { Anode : IMC decreased, Cathode : IMC increased (Reverse } \\
\text { polarity })^{33,36,37)}\end{array}$ \\
\hline $\mathrm{Sn}-0.7 \mathrm{Cu}$ & $\mathrm{Cu}$ OSP & $\mathrm{Cu}_{3} \mathrm{Sn}_{\mathrm{Cu}_{6} \mathrm{Sn}_{5}}$ & Anode : IMC increased, Cathode : IMC decreased (polarity $)^{17)}$ \\
\hline $\mathrm{Sn}-0.7 \mathrm{Cu}$ & $\mathrm{Cu}$ OSP/ENIG & $\begin{array}{l}\mathrm{Cu}_{3} \mathrm{Sn} / \mathrm{Cu}_{6} \mathrm{Sn}_{5} \\
/\left(\mathrm{Ni}, \mathrm{Cu}_{6} \mathrm{Sn}_{5}\right.\end{array}$ & Anode : IMC increased, Cathode : IMC decreased (polarity $)^{42)}$ \\
\hline Sn-3.5Ag & $\mathrm{Cu}$ OSP & $\mathrm{Cu}_{3} \mathrm{Sn} / \mathrm{Cu}_{6} \mathrm{Sn}_{5}$ & $\begin{array}{l}\text { Anode : IMC increased, Cathode : IMC decreased (polarity })^{47)} \\
\text { Cathode : voids and cracks increased }\end{array}$ \\
\hline Sn-3.0Ag-0.5Cu & $\mathrm{Cu}$ OSP/ENIG & $\begin{array}{l}\mathrm{Cu}_{3} \mathrm{Sn} / \mathrm{Cu}_{6} \mathrm{Sn}_{5} \\
/(\mathrm{Ni}, \mathrm{Cu})_{6} \mathrm{Sn}_{5}\end{array}$ & $\begin{array}{l}\text { Anode : IMC increased, Cathode : IMC decreased (polarity })^{47)} \\
\text { Cu OSP : thick IMC formed, ENIG : thin IMC formed }\end{array}$ \\
\hline
\end{tabular}

본 논문은 독자의 이해를 돕기위하여 영문논문을 국문으로 번역하여 게재한 논문입니다. 저자는 본 논문으로 연구업적과 같은 실적에 중복으로 지원받거나 인정받을 수 없음을 알려드립니다. 
여 IMC 층에서 $\mathrm{Sn}$ 성분은 감소하고 $\mathrm{Zn}$ 성분이 크게 증가하면서, 솔더 접합부의 신뢰성이 낮아질 가능성이 높아진다 ${ }^{31)}$. 그러므로 $\mathrm{Sn}-9 \mathrm{Zn}$ 의 내산화성을 향상시키 기 위하여 $\mathrm{Zn}$ 과의 반응성이 우수한 $\mathrm{Ag}$ 를 첨가하여 $\mathrm{ZnO}$ 의 생성을 억제하였다. Fig. $5 \mathrm{~b}$ 에서는 $\mathrm{Sn}-8.5 \mathrm{Zn}$ 솔더와 $\mathrm{Cu}$ 기판의 계면에서 형성되는 $\mathrm{IMC}$ 층은 $\mathrm{Ag}$ 의 첨가로 인하여 $\mathrm{AgZn}_{3}$ 와 $\mathrm{Cu}_{5} \mathrm{Zn}_{8}$ 로 구성되고, $\mathrm{Ag}$ 의 첨 가량이 증가될수록 $\mathrm{Cu}_{5} \mathrm{Zn}_{8}$ 의 $\mathrm{IMC}$ 층이 감소하고 $\mathrm{ag}^{-}$ ing 시간이 증가될수록 IMC 층이 증가하는 경향을 보 인다 ${ }^{32)}$.

Zhang ${ }^{33)}$ 는 $150{ }^{\circ} \mathrm{C}$ 에서 $3.87 \times 10^{3} \mathrm{~A} / \mathrm{cm}^{2}$ 의 전류 밀도로 시간 $(0,36,72$ 및 $166 \mathrm{~h})$ 에 따른 anode와 cathode측의 IMC 두께 변화를 관찰하였으며, 그 결 과를 Fig. 6에 나타낸다. Aging 시간에 따라 anode 측에서는 $72 \mathrm{~h}$ 전류인가 후까지 $\mathrm{Cu}_{5} \mathrm{Zn}_{8}$ 의 $\mathrm{IMC}$ 층 두께가 증가되지만 $166 \mathrm{~h}$ 전류 인가에서는 IMC 층이 감소되는 경향을 보였다. 이렇게 aging 시간에 따라
IMC 층의 두께 증가를 유발하지만 $166 \mathrm{~h}$ 이후 감소 되는 경향은 일반적인 열적 효과와는 반대되는 결과를 보인다. 또한, cathode 측에서도 anode와 유사하게 $72 \mathrm{~h}$ 전류인가 후까지 IMC 층의 두께가 증가되었고, $166 \mathrm{~h}$ 이후에는 IMC 두께가 약 $5.4 \mu \mathrm{m}$ 로 급격하게 증가되었다 (Fig. 6h). 이때, anode측의 IMC 층 두 께는 약 $3.2 \mu \mathrm{m}$ 로 감소되었다 (Fig. 6g). Cathode 측에서 발생된 더 두꺼운 IMC 층의 생성은 일반적으 로 “극성 효과”와 반대되는 특성이며, 이러한 역극성 결 과의 경우가 종종 발생된다고 보고되고 있다 ${ }^{34,35)}$. $\mathrm{Sn}-\mathrm{Zn}$ 계에서 IMC 형성에 영향을 주는 것은 $\mathrm{Zn}$ 입니다. $\mathrm{Sn}$ 원자는 전류 인가 시 전자풍력에 의해서 anode로 이 동합니다. 이와 반대로 back stress가 작용하여 $\mathrm{Zn}$ 원 자는 cathode 쪽으로 이동하여 역극성 결과가 나타나 는 것으로 판단된다.

$\mathrm{Huang}^{36)}$ 은 in-situ 이미지를 통하여 $250{ }^{\circ} \mathrm{C}$ 에서 $1.2 \times 10^{4} \mathrm{~A} / \mathrm{cm}^{2}$ 의 전류밀도로 전류인가 시간에 따 (a)
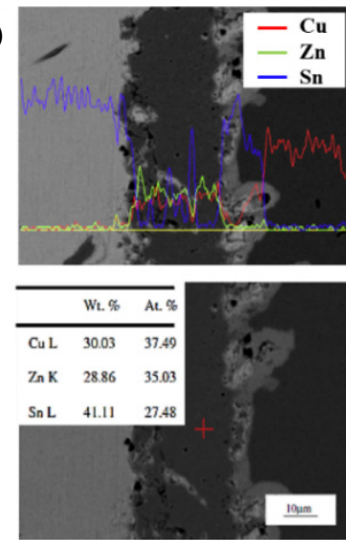

(b)
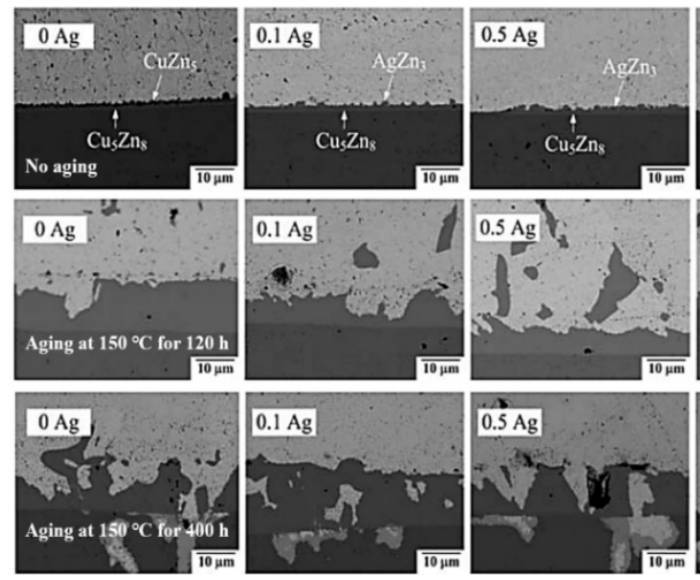

10
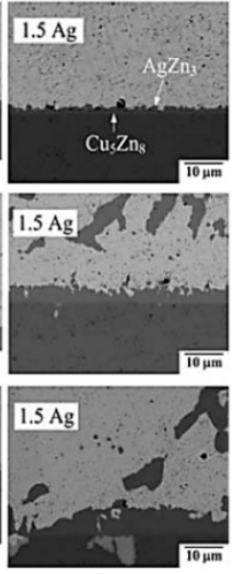

Fig. 5 Growth and component behavior of IMC in the interface between $\mathrm{Sn}-\mathrm{Zn}$ solder and $\mathrm{Cu}$ substrate: (a) component behavior $^{31)}$, (b) effects of Ag content and aging temperature ${ }^{32)}$


Fig. 6 SEM images of IMCs at the anode (left column) and the cathode (right column) for a current density of $3.87 \times 10^{3}$ $\mathrm{A} / \mathrm{cm}^{2}$ and $150{ }^{\circ} \mathrm{C}:(\mathrm{a}, \mathrm{b}) 0 \mathrm{~h},(\mathrm{c}, \mathrm{d}) 36 \mathrm{~h},(\mathrm{e}, \mathrm{f}) 72 \mathrm{~h}$, and $(\mathrm{g}, \mathrm{h}) 166 \mathrm{~h}^{33)}$ 
라 liquid-solid electromigration (L-S EM)에 의 한 IMC 층의 두께변화를 관찰하였으며, 그 결과를 Fig. 7 에 나타낸다. 먼저 전류인가 전 $(0 \mathrm{~min})$ 에는 솔 더 계면에 약간의 기포가 발생되어 솔더가 녹기 시작하 였으며 (Fig. 7a), L-S EM이 $5 \mathrm{~min}$ 진행된 이후, anode와 cathode의 각 계면에서 연속적인 IMC 층이 생성되었다 (Fig. $7 \mathrm{~b}$ ). 그리고 $8 \mathrm{~min}$ 후에는 노란색 원으로 표시된 cathode 측 계면에서 $\mathrm{IMC}$ 가 성장되었 으나, 흰색 점선으로 표시된 anode의 IMC 층은 용해 되거나 $\mathrm{Cu}$ 가 소모되는 현상을 보인다. 또한, $\mathrm{L}-\mathrm{S} \mathrm{EM}$ 시간이 길어질수록 cathode 측에 생성된 $\mathrm{IMC}$ 층이 $\mathrm{Sn}-9 \mathrm{Zn}$ 솔더까지 두껍게 성장하지만, anode측 계면 에 생성된 IMC 층은 매우 얇은 결과를 보였다. 이러 한 결과는 cathode 측의 $\mathrm{Cu}$ 의 소모는 제한되어 IMC 층의 성장을 유도하지만, anode측 $\mathrm{Cu}$ 의 용해는 가속 화되는 것을 보여준다.

$\mathrm{Ku}^{37)}$ 의 연구에서는 $130{ }^{\circ} \mathrm{C}$ 에서 $1.0 \times 10^{3} \mathrm{~A} / \mathrm{cm}^{2}$ 의 전류밀도로 100 및 $185 \mathrm{~h}$ 동안 전류를 인가한 후, focused ion beam (FIB)로 준비된 시편의 TEM 이 미지를 통하여 anode 측 $\mathrm{Sn}-9 \mathrm{Zn}$ 솔더와 $\mathrm{Cu}$ 계면에 형성된 IMC 거동을 관찰한 결과를 Fig. 8에 나타낸다. Fig. 8의 결과는 Huang ${ }^{36)}$ 연구에서 anode 측 $\mathrm{Cu}$ 의 가속화된 용해 및 소모를 메커니즘적으로 설명하였다. Figs. $8 \mathrm{a}$ 및 $8 \mathrm{~b}$ 은 $100 \mathrm{~h}$ 동안 전류를 인가한 anode
측 솔더/ $\mathrm{Cu}$ 계면의 $\mathrm{IMC}$ 형성 거동 및 메커니즘을 나 타낸다. Anode 측 솔더 $/ \mathrm{Cu}$ 계면에서 길이방향의 층상 $\mathrm{Cu}_{5} \mathrm{Zn}_{8} \mathrm{IMC}$ 가 형성되었으며, $\mathrm{Cu}_{5} \mathrm{Zn}_{8} \mathrm{IMC} / \mathrm{Cu}$ 계면에 서는 $\mathrm{Cu}_{6} \mathrm{Zn}_{5}$ 의 $\mathrm{IMC}$ 가 관찰되었다(Fig. $8 \mathrm{a}$ ). 전류가 인가되면 길이방향의 $\mathrm{r}^{-} \mathrm{Cu}_{5} \mathrm{Zn}_{8}$ 상의 결정립계가 전자 의 이동 방향에 거의 평행하기 때문에 $\mathrm{EM}$ 에 의하여 $\mathrm{Sn}$ 원자가 $\mathrm{\gamma}^{-} \mathrm{Cu}_{5} \mathrm{Zn}_{8}$ 의 결정립계를 통하여 빠르게 이 동하게 된다. 따라서 anode 측 $\mathrm{Cu}_{5} \mathrm{Zn}_{8} \mathrm{IMC} / \mathrm{Cu}$ 계 면에서 $\mathrm{Sn}$ 의 축적과 $\mathrm{Cu}$ 의 상호작용을 통하여 $\mathrm{Cu}_{6} \mathrm{Sn}_{5}$ 의 $\mathrm{IMC}$ 가 형성된다(Fig. 8b). 전류인가 $185 \mathrm{~h}$ 이후 에는 $\mathrm{Cu}_{6} \mathrm{Sn}_{5} \mathrm{IMC}$ 층의 성장으로 인해 anode 측 $\mathrm{Cu}$ 의 상대적으로 심각한 소모되는 결과를 보인다(Fig. 8c). $\mathrm{Sn}$ 내 $\mathrm{Cu}$ 의 확산이 $\mathrm{Cu}$ 내 $\mathrm{Sn}$ 의 확산보다 더 지배적으로 이루어지기 때문에 $\mathrm{EM}$ 을 통해 anode 측 $\mathrm{Cu}$ 층으로 $\mathrm{Sn}$ 이 이동하면서 $\mathrm{Cu}_{5} \mathrm{Zn}_{8} \mathrm{IMC} / \mathrm{Cu}$ 계면에 서 $\mathrm{Cu}_{6} \mathrm{Sn}_{5} \mathrm{IMC}$ 를 생성한 후에 anode 측 $\mathrm{Cu}$ 층에 형 성되어 $\mathrm{Cu}$ 의 소모를 설명해 준다(Fig. $8 \mathrm{~d}$ ).

\section{$3.2 .2 \mathrm{Sn}-\mathrm{Cu}$ 계 솔더 접합부 특성}

$\mathrm{Sn}-0.7 \mathrm{Cu}$ 합금의 미세조직은 $\beta-\mathrm{Sn}$ 및 $\mathrm{Cu}_{6} \mathrm{Sn}_{5} / \beta-$ $\mathrm{Sn}$ 공정조성으로 구성되며, 이 합금계의 미세조직은 Fig. 9에 나타낸 ${ }^{38)}$. $\mathrm{Hung}^{39)}$ 의 연구는 $\mathrm{Cu}$ 함유량에 따른 $\mathrm{Sn}^{-} x \mathrm{Cu}$ 의 미세조직 변화를 관찰하였으며, $\mathrm{Cu}$ 함유량의 증가에 따라 $\mathrm{Cu}_{6} \mathrm{Sn}_{5}$ 의 $\mathrm{IMC}$ 는 증가되나, $\beta$

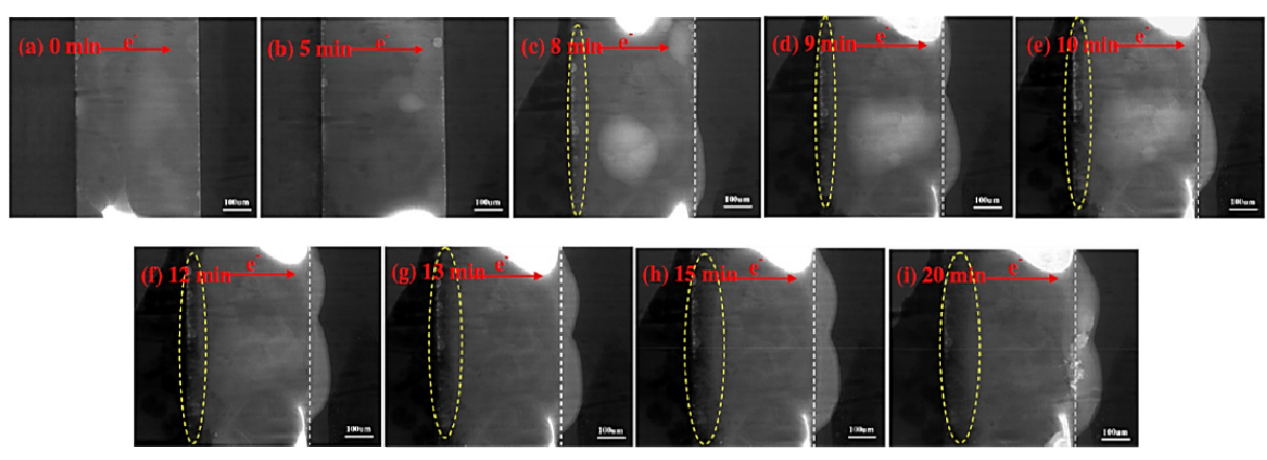

Fig. 7 In situ observation of L-S EM of the $\mathrm{Cu} / \mathrm{Sn}-9 \mathrm{Zn} / \mathrm{Cu}$ interconnect under a current density of $1.2 \times 10^{4} \mathrm{~A} / \mathrm{cm}^{2}$ at $250{ }^{\circ} \mathrm{C}$ for (a) $0 \mathrm{~min}$, (b) $5 \mathrm{~min}$, (c) $8 \mathrm{~min}$, (d) $9 \mathrm{~min}$, (e) $10 \mathrm{~min}$, (f) $12 \mathrm{~min}$, (g) $13 \mathrm{~min}$, (h) $15 \mathrm{~min}$, and (i) $20 \mathrm{~min}$, respectively $^{36)}$
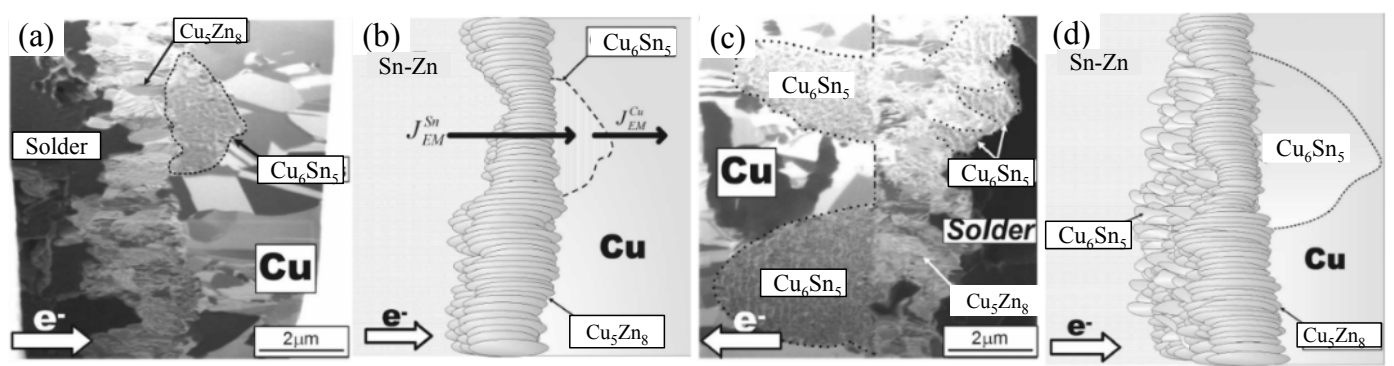

Fig. 8 TEM images for anode area of Sn-Zn solder/Cu interface after current stressing at $1.0 \times 10^{3} \mathrm{~A} / \mathrm{cm}^{2}$ : (a) $100 \mathrm{~h},(\mathrm{~b})$ mechanism at $100 \mathrm{~h}$, (c) $185 \mathrm{~h}$, and (d) mechanism at $185 \mathrm{~h}^{37)}$ 

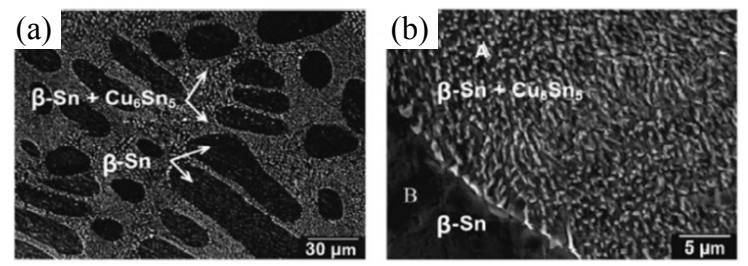

Fig. 9 Microstructure of $\mathrm{Sn}-0.7 \mathrm{Cu}$ alloy ${ }^{38)}$ : (a) the shape of each phase, (b) magnified image of the interface between $\beta$-Sn and eutectic mixture

-Sn 상은 미세해지는 경향을 보였다. 기지에 고르게 분산된 다량의 $\mathrm{IMC}$ 가 강화 메커니즘의 역할을 하나. $\mathrm{Cu}$ 함유량에 따라 솔더의 용융점 또한 크게 상승되므 로 적절한 첨가가 필요하다. 또한 $\mathrm{Yang}^{40)}$ 와 $\mathrm{El}-$ $\mathrm{Daly}^{41)}$ 는 $\mathrm{Sn}-0.7 \mathrm{Cu}$ 합금에 $\mathrm{Al}$ 및 $\mathrm{Ag}$ 성분을 첨가하 여 솔더 접합부의 전기/열전도성 및 솔더 접합성을 향 상을 위한 연구를 진행하였으며, 다양한 IMC의 분율 이 증가하며, $\beta-\mathrm{Sn}$ 상은 미세해지는 결과를 보였다.

$\mathrm{Baek}^{17)}$ 의 연구에서는 $\mathrm{Sn}-0.7 \mathrm{Cu}$ 의 솔더 접합부에 서 $\mathrm{IMC}$ 의 생성 및 성장과 관련 있는 $\mathrm{EM}$ 과 $\mathrm{TM}$ 의 영 향을 관찰하였다. 전류의 직진성과 온도구배의 정확한 구현을 위하여 시편을 제작하였고, 이를 통하여 $\mathrm{IMC}$ 성장 모델링 결과와 비교하였다. Fig. $10 \mathrm{a}$ 는 $120{ }^{\circ} \mathrm{C}$ 에서 $6 \mathrm{~A}$ 의 정전류 및 $10 \mathrm{kA} / \mathrm{cm}^{2}$ 의 전류밀도로 $0^{-}$ $300 \mathrm{~h}$ 동안 전류를 인가한 후 $\mathrm{EM}$ 에 의한 IMC 두께 변화를 나타낸다. $\mathrm{Sn}-0.7 \mathrm{Cu} / \mathrm{Cu}$ 의 계면에서 생성된 $\mathrm{IMC}$ 층은 주로 $\mathrm{Cu}_{6} \mathrm{Sn}_{5}$ 및 $\mathrm{Cu}_{3} \mathrm{Sn}$ 으로 구성되며, 전 류인가 시간이 길어질수록 $\mathrm{IMC}$ 층이 두꺼워지는 결과 를 보였다. 특히, 전류인가 $200 \mathrm{~h}$ 이후, $\mathrm{Cu}_{6} \mathrm{Sn}_{5}$ 의 $\mathrm{IMC}$ 층과 $\mathrm{Sn}-0.7 \mathrm{Cu}$ 솔더 간의 계면에 존재하는 void 분율은 동시에 증가하므로, IMC와 void의 성장 은 단전 결함과 밀접한 상관관계를 보였다. Fig. $10 \mathrm{~b}$ 는 $55 / 150{ }^{\circ} \mathrm{C}$ 의 가열 및 냉각조건에서 0-300 h 동안 온도를 유지한 이후 $\mathrm{TM}$ 에 의한 IMC 층의 두께 변화 를 나타낸다. Fig. $10 \mathrm{a}$ 와 동일하게 $\mathrm{TM}$ 에 의해 솔더 $/ \mathrm{Cu}$ 계면에 생성된 $\mathrm{IMC}$ 는 $\mathrm{Cu}_{6} \mathrm{Sn}_{5}$ 및 $\mathrm{Cu}_{3} \mathrm{Sn}$ 으로 구 성되며, 온도 유지시간이 증가됨에 따라 IMC 층의 소
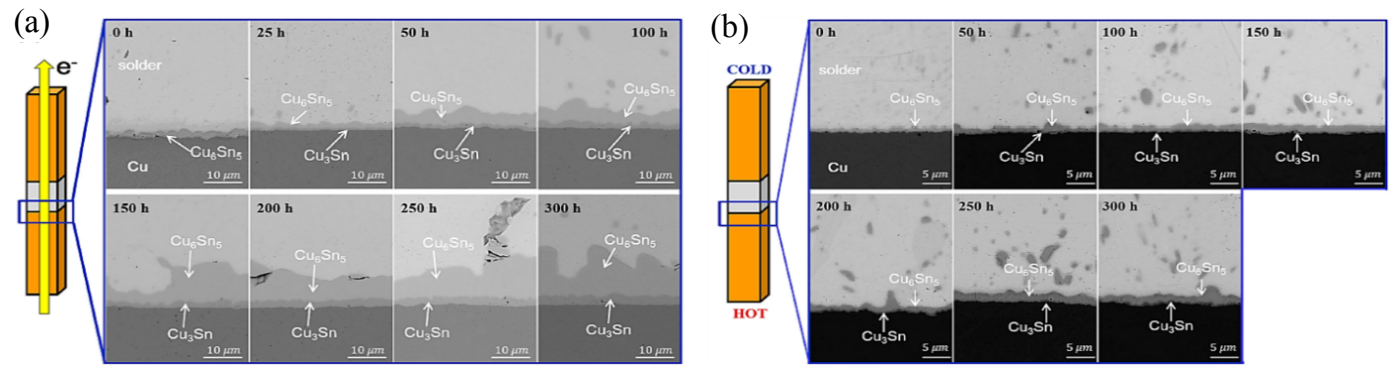

Fig. 10 SEM image of an IMC grown by (a) EM and (B) $\mathrm{TM}^{17)}$ 
높은 2-3 배 정도의 성장율이 확인되었다. 따라서, 전 류밀도가 증가되면 $\mathrm{IMC}$ 의 성장과 관련된 현상에서 $\mathrm{EM}$ 이외에도 Joule 열 효과에 의한 Aging 및 TM 효과 등을 고려할 필요가 있음을 밝혔단)

\subsection{3 $\mathrm{Sn}-\mathrm{Ag}$ 계 솔더 접합부의 특성}

$\mathrm{Sn}-3.5 \mathrm{wt} \% \mathrm{Ag}$ 공정합금은 거의 순수한 $\beta-\mathrm{Sn}$ 과 $\varepsilon^{-}$ $\mathrm{Ag}_{3} \mathrm{Sn}$ 상의 미세조직으로 구성되어 있다. Fig. 13은 2단(CR1-CR2) 냉각에 따라 $\mathrm{Sn}$ 기지에 침상형태의 $\mathrm{Ag}_{3} \mathrm{Sn}$ 가 응고 방향을 따라 성장하고, 솔더링 중에 냉각 속도가 빠르게 되면 (P1) 핵생성이 촉진되어 $\mathrm{Ag}_{3} \mathrm{Sn}$ 의 성장이 방해되고 미세하게 분산된 조직을 나타낸달) 미세하게 분산된 $\varepsilon-\mathrm{Ag}_{3} \mathrm{Sn}$ 상의 특징으로 인한 분산강 화효과로 기계적 강도가 공정조성인 $3.5 \mathrm{wt} \% \mathrm{Ag}$ 에서 가장 뛰어난 효과를 가진다 ${ }^{25)} . \mathrm{Sn}-3.5 \mathrm{Ag}$ 솔더와 $\mathrm{Cu}$ 기 판 $(\mathrm{Sn}-3.5 \mathrm{Ag} / \mathrm{Cu})$ 간의 $\mathrm{IMC}$ 층은 주로 $\mathrm{Cu}_{3} \mathrm{Sn}$ 와 $\mathrm{Cu}_{6} \mathrm{Sn}_{5}$ 으로 구성되며, 섬유상 형태로 분산된 $\mathrm{Ag}_{3} \mathrm{Sn}$ 상이 존재한다. Fig. 14는 $\mathrm{Sn}-\mathrm{Ag}$ 계 솔더 접합부에서 솔더 중 $\mathrm{Ag}$ 의 함량 및 리플로 온도가 IMC 성정거동에

Table 2 Primary and secondary cooling rates at measurement position P1-P4 in continuous cooling experiment $^{43)}$

\begin{tabular}{|c|c|c|c|c|}
\hline Position & P1 & P2 & P3 & P4 \\
\hline $\mathrm{CR} 1\left({ }^{\circ} \mathrm{C} / \mathrm{s}\right)$ & 263.6 & 116 & 43.9 & 27.1 \\
\hline $\mathrm{CR} 2\left({ }^{\circ} \mathrm{C} / \mathrm{s}\right)$ & 113.6 & 42.1 & 30.8 & 21.6 \\
\hline
\end{tabular}

미치는 영향과 관련된 연구 결과를 나타낸다. $\mathrm{Ag}$ 의 농 도가 높을수록 $\mathrm{Cu}_{6} \mathrm{Sn}_{5}$ 의 평균 결정립 수가 증가하며, 리플로 온도가 낮을수록 결정립의 폭이 감소되는 경향 을 보이는 것으로 알려져 있다 ${ }^{44)}$.

Jung ${ }^{45)}$ 의 연구에서는 $\mathrm{Cu} / \mathrm{Sn}-3.5 \mathrm{Ag} / \mathrm{Cu}$ 접합부의 전류인가 시간에 따른 anode와 cathode측의 IMC 및 Kirkendall void 성장거동을 조사하였다. Fig. 15는 $150{ }^{\circ} \mathrm{C}$ 에서 전류인가 없이 0-200 h의 시간변화에 따 른 $\mathrm{Sn}-3.5 \mathrm{Ag} / \mathrm{Cu}$ 솔더 계면의 $\mathrm{IMC}$ 성장 거동을 나타 낸다. Aging 시간의 증가에 따라 주된 $\mathrm{IMC}$ 인 $\mathrm{Cu}_{3} \mathrm{Sn}$ 및 $\mathrm{Cu}_{6} \mathrm{Sn}_{5}$ 층이 성장되며, aging $100 \mathrm{~h}$ 이후부터 대 부분의 Kirkendall void가 $\mathrm{Cu}_{3} \mathrm{Sn} / \mathrm{Cu}$ 의 계면에 생성 되었다. Aging 시간의 증가는 void의 연속적인 핵생성 및 성장을 유발하며, $200 \mathrm{~h}$ 후에는 void가 $\mathrm{Cu}_{3} \mathrm{Sn} / \mathrm{Cu}$ 계면을 완전히 덮는 결과를 보인다. $400 \mathrm{~h}$ 후 $\mathrm{Cu}_{3} \mathrm{Sn} / \mathrm{Cu}$ 계면에 생성된 void의 위치가 $\mathrm{Cu}_{3} \mathrm{Sn} / \mathrm{Cu}_{6} \mathrm{Sn}_{5}$ 계면으 로 이동한다. 그 원인은 $\mathrm{Cu}_{3} \mathrm{Sn}$ 이 $\mathrm{Cu}_{6} \mathrm{Sn}_{5}$ 로 변환되 고, $\mathrm{Cu}_{6} \mathrm{Sn}_{5} / \mathrm{Cu}$ 계면에서 새로운 $\mathrm{Cu}_{3} \mathrm{Sn}$ 이 생성되었 기 때문이다.

Fig. 16 은 $150{ }^{\circ} \mathrm{C}$ 에서 $1 \times 10^{4} \mathrm{~A} / \mathrm{cm}^{2}$ 의 전류밀도 로 40-150 h 동안 전류인가 후, anode/cathode의 $\mathrm{IMC}$ 성장거동 및 Kirkendall void 분율을 나타낸다. $\mathrm{EM}$ 이 IMC의 두께뿐만 아니라 Kirkendall void의 분율에도 극성효과를 미치고 있음을 확인하였다. 전류 인가 시간에 따라 $\mathrm{Cu}_{3} \mathrm{Sn}$ 의 두께는 큰 차이가 없으므 로 IMC 두께의 극성효과는 주로 $\mathrm{Cu}_{6} \mathrm{Sn}_{5}$ 에 의해서 야
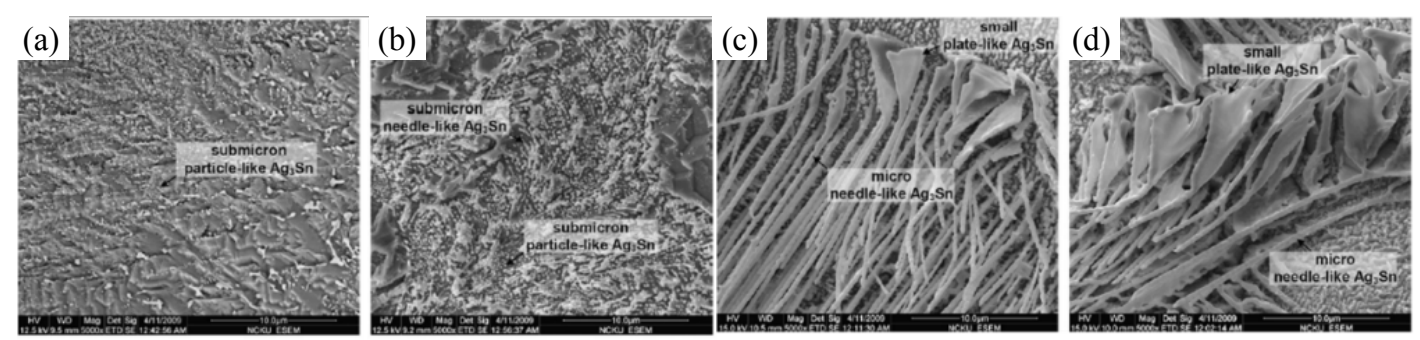

Fig. 13 3D SEM morphologies of Ag3Sn compounds at measurement positions P1-P4 in continuous cooling experiment ${ }^{43)}$ : (a) P1, (b) P2, (c) P3, and (d) P4
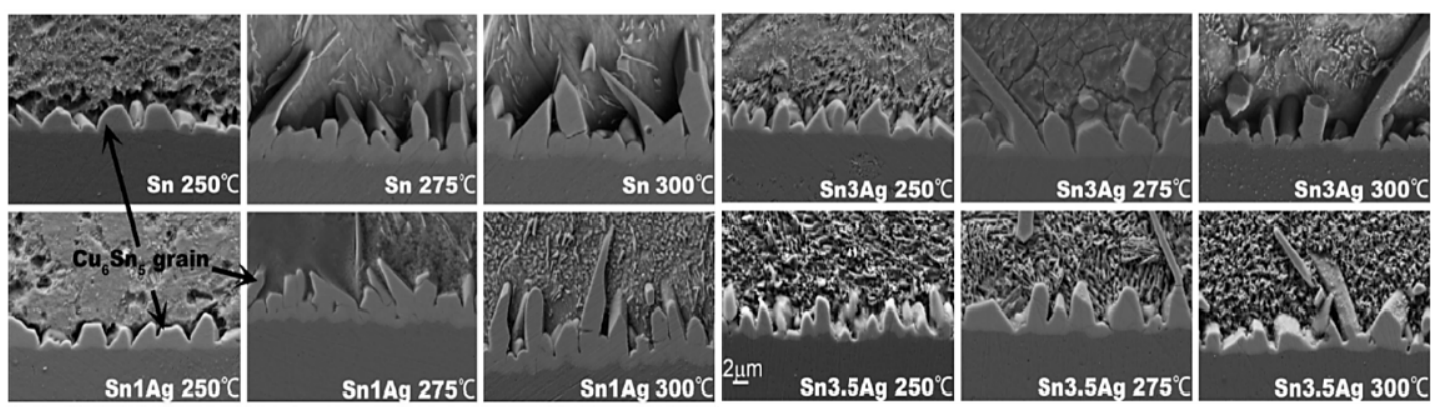

Fig. 14 Cross-sectional SEM images of air-cooled solder alloys to indicate $\mathrm{Cu}_{6} \mathrm{Sn}_{5}$ grains for various magnitudes of pre-cooled isothermal reflow temperature and $\mathrm{Ag}$ concentrations ${ }^{44)}$ 
(a)
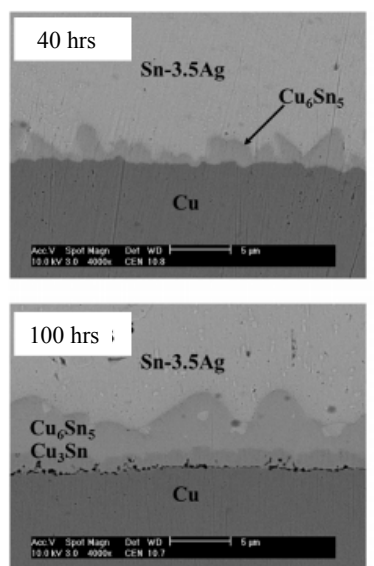
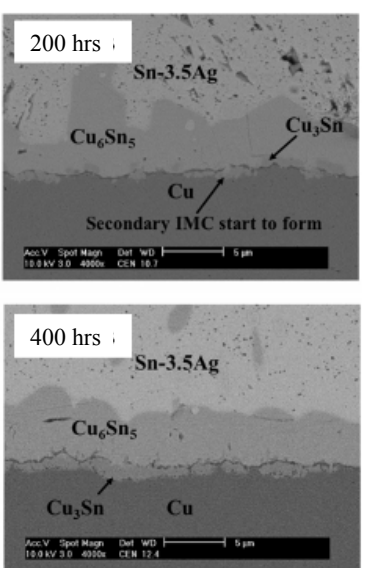

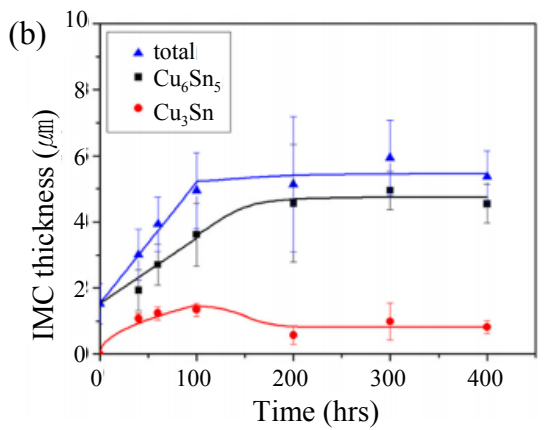

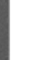 \\ .}

Fig. $15 \mathrm{Sn}-3.5 \mathrm{Ag} / \mathrm{Cu}$ solder joint aged at $150{ }^{\circ} \mathrm{C}$ without electricity flow for 0-400 h: (a) Cross-sectional SEM images, (b) thickening of IMC at the solder joint ${ }^{45)}$

(a)

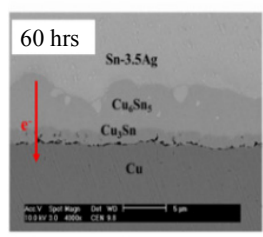

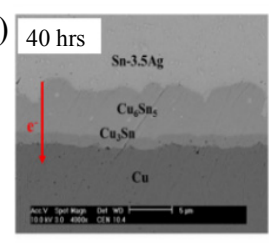
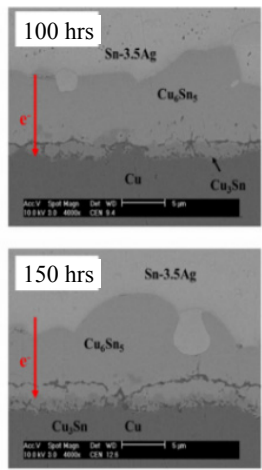

(b)
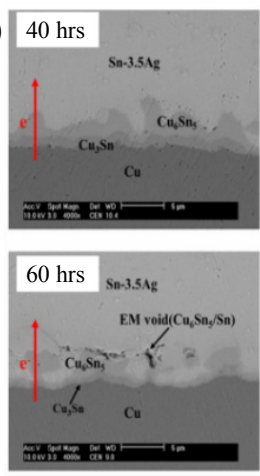

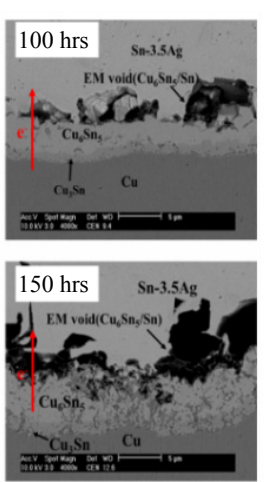

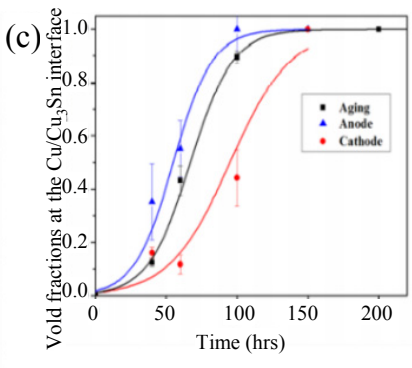

Fig. 16 Cross-sectional SEM images of Sn-3.5Ag/Cu solder joint aged at $150{ }^{\circ} \mathrm{C}$ under the electric current density of $1 \times$ $1^{04} \mathrm{~A} / \mathrm{cm}^{2}$ : (a) the anode side, (b) the cathode side, (c) fraction of Kirkendall void after $40-150 \mathrm{~h}^{45}$ )
기되며, anode 측에서는 IMC 및 void의 성장이 가속 화되지만, cathode 측의 성장속도는 감소된 결과를 보 였다. Anode 측의 전류인가 시간에 따른 Kirkendall void 생성 및 성장거동은 전류를 인가하지 않은 경우와 거의 유사하였다. 그러나 cathode 측에서는 $\mathrm{Cu}_{3} \mathrm{Sn} / \mathrm{Cu}$ 의 계면에 void가 생성되며, $100 \mathrm{~h}$ 이후에는 Kirkendall void가 $\mathrm{Cu}_{6} \mathrm{Sn}_{5} / \mathrm{Sn}$ 계면의 대부분을 차지하며, 150 $\mathrm{h}$ 에서는 $\mathrm{Cu}_{6} \mathrm{Sn}_{5} / \mathrm{Sn}$ 계면에서 Kirkendall void가 포 화되어 미세 균열의 생성이 야기되는 결과를 보였다. 이러한 Kirkendall void의 생성 및 성장은 솔더 접합 부의 손상거동에 대한 수명에 영향을 미치는 것으로 보 고된다 ${ }^{3)}$.

\subsubsection{Sn-Ag-Cu계 솔더 접합부 특성}

$\mathrm{Sn}-3.5 \mathrm{wt} \% \mathrm{Ag}-0.7 \mathrm{wt} \% \mathrm{Cu}$ 공정합금은 일반적으로 $\mathrm{Sn}-3.5 \mathrm{Ag}$ 합금과 거의 유사한 미세조직을 가진다. Fig. 17 은 미량의 $\mathrm{Cu}$ 첨가로 인하여 구성 조직인 $\beta-\mathrm{Sn}$ 과 $\mathrm{Sn} / \mathrm{Ag}_{3} \mathrm{Sn}$ 의 공정상 그리고 $\varepsilon-\mathrm{Ag}_{3} \mathrm{Sn}$ 상 중에 $\eta^{-} \mathrm{Cu}_{6} \mathrm{Sn}_{5}$ 의 정출상이 존재하게 된다 ${ }^{46)}$. 따라서 $\mathrm{Ag}$ 함량이 높은 (a)
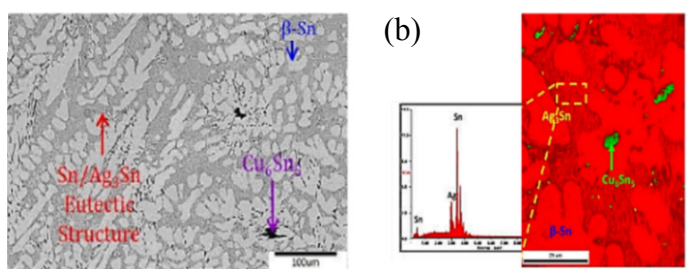

Fig. 17 Microstructure of SAC305 joint: (a) microstructure at solder matrix, (b) EBSD image with inverse pole figure (IPF) $)^{47)}$

조성에서 생성되는 조대한 $\mathrm{Ag}_{3} \mathrm{Sn}_{\mathrm{S}}$ 상의 형성을 방지하 기 위하여 $\mathrm{Sn}-3.0 \mathrm{Ag}-0.5 \mathrm{Cu}$ 합금이 대표적인 합금으 로 자리잡고 있다.

Fig. $18 \mathrm{a}$ 는 $\mathrm{Sn}-3.0 \mathrm{Ag}-0.5 \mathrm{Cu}$ 솔더와 $\mathrm{Cu}$ 기판 ( $\mathrm{SAC}^{-}$ $305 / \mathrm{Cu}$ 간의 $\mathrm{IMC}$ 층은 주로 $\mathrm{Cu}_{3} \mathrm{Sn}$ 와 $\mathrm{Cu}_{6} \mathrm{Sn}_{5}$ 으로 구성되고, $\mathrm{Sn} / \mathrm{Ag}_{3} \mathrm{Sn}$ 의 공정상이 존재함을 나타낸다 ${ }^{47)}$. Figs. $18 \mathrm{~b}$ 와 $18 \mathrm{c}$ 는 냉각방법(냉각속도)에 따른 IMC 층/기지 조직 경계의 미세조직 변화를 SEM 이미지 및 모식도로 각각 표현한 것이다. 빠른 냉각속도에 의해서 기지의 $\mathrm{Ag}_{3} \mathrm{Sn}_{\text {과 }} \mathrm{Cu}_{6} \mathrm{Sn}_{5}$ 금속간 화합물의 크기 및 분 
(a)

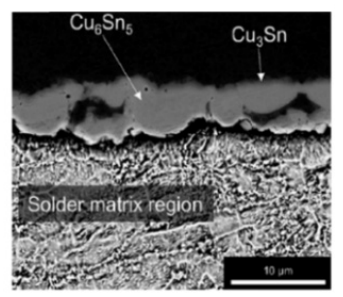

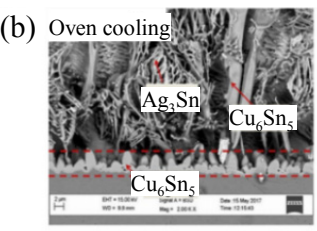

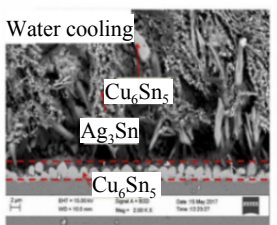

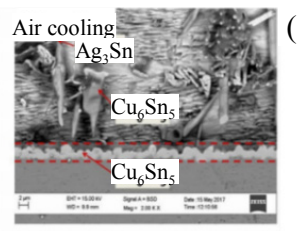

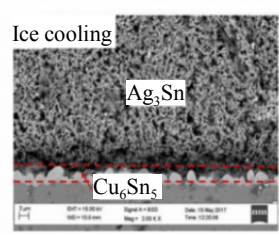

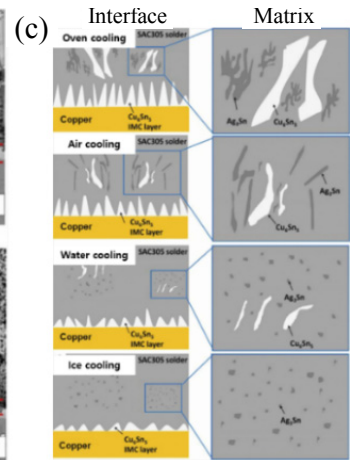

Fig. 18 Growth behavior of IMC in the interface between SAC305 solder and $\mathrm{Cu}$ substrate: (a) configuration of IMC lay$\mathrm{er}^{47}$, (b) formation of microstructure by cooling methods ${ }^{48}$, and (c) schematic diagram of microstructure ${ }^{48)}$

(a) As bonded

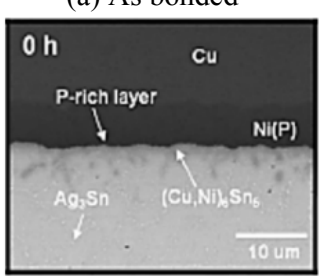

OSP

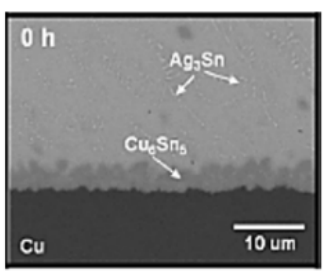

(b) Annealing
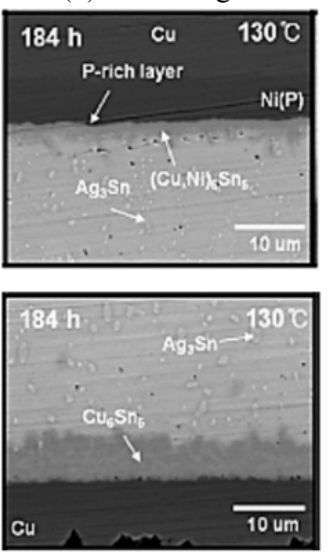

(c) e-downstream
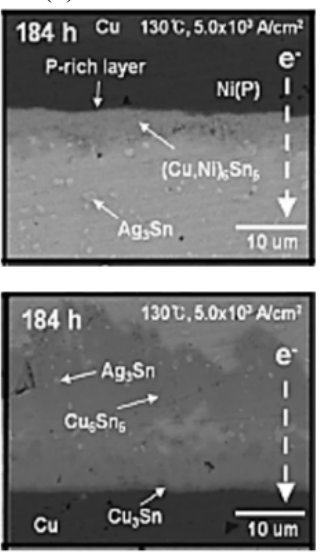

(d) e-upstream
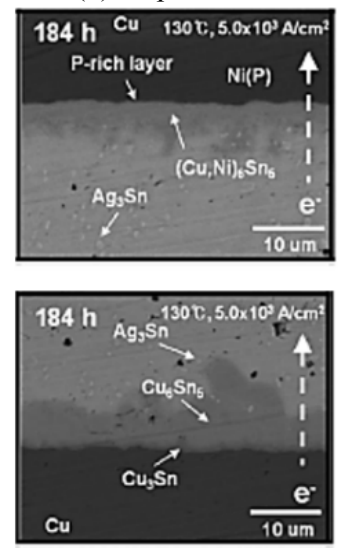

Fig. 19 SEM images of ENIG and OSP interfaces of cross-sectioned SAC305 solder ${ }^{49)}$ : (a) as-bonded, (b) annealing after $184 \mathrm{~h}$ at $130{ }^{\circ} \mathrm{C}$, (c) electron downstream and (d) upstream at $5.0 \times 10^{3} \mathrm{~A} / \mathrm{cm}^{2}$ for $184 \mathrm{~h}$

율이 감소되며, $\mathrm{SAC} 305 / \mathrm{Cu}$ 경계에 존재하는 IMC $\left(\mathrm{Cu}_{6} \mathrm{Sn}_{5}\right)$ 층도 감소시키는 것으로 알려져 있다 ${ }^{48)}$.

$\mathrm{Kim}^{49)}$ 은 $\mathrm{SAC} 305$ 솔더 접합부의 상/하부에 따른 열처리의 영향 및 전류인가에 의한 $\mathrm{IMC}$ 성장 거동을 조사하였다. 솔더 접합 직후에 상부 접합부의 $\mathrm{ENIG}$ 표면처리에서는 $\left(\mathrm{Cu}, \mathrm{Ni}_{6} \mathrm{Sn}_{5}\right.$, 하부 접합부의 organic solderability preservative (OSP) 표면 처리에서는 $\mathrm{Cu}_{6} \mathrm{Sn}_{5}, \mathrm{Cu}_{3} \mathrm{Sn}$ 의 $\mathrm{IMC}$ 가 접합계면에 생성되었다(Fig. 19a). $130{ }^{\circ} \mathrm{C}$ 에서 $184 \mathrm{~h}$ 동안의 열처리 조건 하에서는 $\mathrm{OSP}$ 에서의 $\mathrm{Cu}_{6} \mathrm{Sn}_{5}, \mathrm{Cu}_{3} \mathrm{Sn}$ 의 IMC가 ENIG에서의 $(\mathrm{Cu}, \mathrm{Ni})_{6} \mathrm{Sn}_{5}$ 보다 더 두껍게 성장하였으며(Fig. 19b), 그 원인은 고온 분위기에서 $\mathrm{Cu}$ 의 확산이 급속하게 이 루어져 $\mathrm{Cu}_{6} \mathrm{Sn}_{5}$ 의 $\mathrm{IMC}$ 상이 빠르게 성장된 결과이다. Figs. $19 \mathrm{c}$ 및 $19 \mathrm{~d}$ 는 $130{ }^{\circ} \mathrm{C}$ 에서 $5.0 \times 103 \mathrm{~A} / \mathrm{cm}^{2}$ 의 전류밀도로 $184 \mathrm{~h}$ 동안 전류 인가 후, 전자 방향에 따른 $\mathrm{IMC}$ 성장거동을 나타내었다. 전류가 인가됨에 따 라 $\mathrm{IMC}$ 의 두께가 증가하는 경향을 보였으며, 전자방향과 상관없이 $\mathrm{ENIG}$ 에서의 $\left(\mathrm{Cu}, \mathrm{Ni}_{6}{ }_{6} \mathrm{Sn}_{5} \mathrm{IMC}\right.$ 층은 얇게 형성되었으나, $\mathrm{OSP}$ 에서의 두꺼운 $\mathrm{Cu}_{6} \mathrm{Sn}_{5}$ 를 관찰된
다. 전자가 아래로 흐를 경우, 위로 흐르는 경우의 보 다 2 배 정도 $\mathrm{Cu}_{6} \mathrm{Sn}_{5} \mathrm{IMC}$ 층이 더 두껍게 형성되었 다. 이는 전자가 아래로 흐르는 경우, 솔더와 $\mathrm{Cu}$ 의 확 산에 의한 IMC 생성 및 솔더 내부에 존재하는 $\mathrm{Cu}$ 가 전자방향에 의해서 OSP 쪽 계면에 쌓이게 된다. 이러 한 $\mathrm{IMC}$ 성장거동의 원인은 $\mathrm{EM}$ 현상에 의한 극성효과 (polarity effect) 때문이다 ${ }^{50)}$. 또한 표면처리의 종류 가 확산되는 정도의 차이를 변화시킨다. $\mathrm{ENIG}$ 표면처 리의 경우 도금된 $\mathrm{Ni}$ 층이 $\mathrm{Cu}$ 의 확산 방지층 역할을 하여 $\mathrm{Cu}$ 의 확산을 억제시킨다. 따라서, $\mathrm{ENIG}$ 표면처 리의 경우 $\mathrm{OSP}$ 표면처리에 비해서 $\mathrm{IMC}$ 가 덜 성장하 였다.

일반적으로 $\mathrm{Cu}$ 기판과 $\mathrm{SAC} 305$ 의 접합부에서는 솔 더와의 빠른 반응성으로 인한 $\mathrm{Cu}_{6} \mathrm{Sn}_{5}$ 및 $\mathrm{Cu}_{3} \mathrm{Sn}$ 과 같 은 $\mathrm{IMC}$ 의 빠른 생성이 접합부 신뢰성을 저하시키는 문제가 있다 ${ }^{49)}$. 이 문제를 개선하기 위하여 확산방지층 역할을 하는 $\mathrm{Ni}$ 도금기술이 적용되고 있으며, 주로 무 전해 니켈-침지금(electroless nickel immersion gold, ENIG) 및 무전해 니켈-무전해 팔라듐-침지금 
(electroless nickel electroless palladium immersion gold, ENEPIG) 도금층이 사용되고 있다 ${ }^{51,52)}$. 이러한 표면처리는 패키지의 신뢰성에 영향을 미치며, 나아가 패키지의 수명에도 실질적인 연관성이 있다. 그 러므로 최근 ENIG와 ENEPIG 표면처리가 우수한 젖 음 및 무전해 도금특성, 그리고 뛰어난 확산방지 특성 으로 인해 미세 피치 플립칩 (fine pitch flip chip) 공정 둥의 $\mathrm{UBM}$ (under bump metallization) 재료 로 사용되고 있다.

\section{3 솔더 접합부 기술개발의 향후 동향}

전자 패키징 내의 $\mathrm{PCB}$ 표면처리 층 위에서 솔더링 등의 접합공정이 이루어지므로, 표면처리 특성에 따라 접합성 및 패키지 자체의 장기적 신뢰성이 큰 영향을 받는다. 다양한 솔더합금은 $\mathrm{Sn}$ 이 주요 합금원소 이므 로 솔더의 종류보다는 기판의 표면처리 방법이 $\mathrm{EM}$ 에 중요한 영향을 미친다. 대표적인 표면처리법은 $\mathrm{Cu} \mathrm{OSP}$, HASL (hot air solder leveling), 침지 주석 (immersion tin), 침지 은 (immersion silver), ENIG 및 ENEPIG 가 있으나, 직접적으로 $\mathrm{Cu}$ 기판이 드러나는 표면처리 보다는 무전해 도금 기술인 ENIG 및 ENEPIG 표면 처리가 주로 사용된다 ${ }^{53,54)}$.

특히, ENIG 보다 ENEPIG 표면처리 층이 야금학 적이나 기계적 신뢰성이 우수하다고 보고된다. 그 원인 은 $\mathrm{ENEPIG}$ 층의 $\mathrm{Au}$ 및 $\mathrm{Ni}$ 층 사이에 존재하는 $\mathrm{Pd}$ 층으로 인한 $\mathrm{Ni}_{3} \mathrm{Sn}_{4}$ 와 $\mathrm{Ni}_{3} \mathrm{P}$ 의 IMC 및 Kirkendall void의 생성을 억제하기 때문이다 55). 하지만 기존에 사용되던 ENEPIG 표면처리는 $\mathrm{Ni}$ 의 두께가 약 3-7 $\mu \mathrm{m}$ 로 두꺼우므로 가속화되는 미세피치 기술을 만족시키 려면 솔더 간의 간격 감소 및 전기저항 증가에 의한 결 함발생이 증가된다는 문제점이 있다 ${ }^{56)}$. 이러한 단점을 해결하기 위하여 $\mathrm{Ni}$ 층의 두께를 $1 \mu \mathrm{m}$ 미만으로 얇은 표면처리 기술이 개발되고 있으며 (Fig. 20), 다양한 연구가 진행 중이다 ${ }^{56,57)}$.

얇은 ENEPIG 표면처리는 미세피치 기술에 대한 적 용성이 우수하며, 솔더링 뿐만 아니라 다양한 접합방법 에도 적용이 가능하다. 또한, 양호한 내열성 및 도금밀 착성, 더 나아가 공정가격을 저감 시키는 장점을 가지

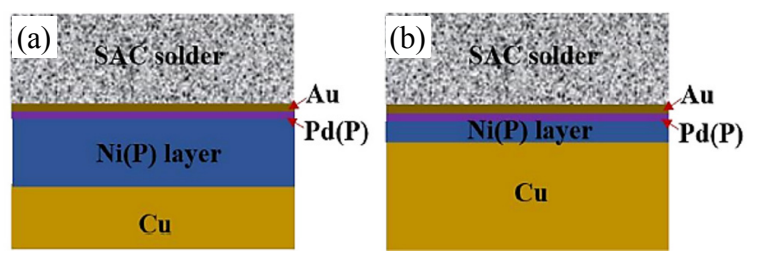

Fig. 20 Schematics of surface finishes: (a) normal- and (b) thin-ENEPIG
므로 연구개발에 대한 적용범위가 확대될 것으로 전망 된다 ${ }^{58)}$. 현재 많은 연구기관에서 $1 \mu \mathrm{m}$ 미만의 $\mathrm{ENEPIG}$ 표면 처리를 적용한 솔더 접합부의 특성에 대한 연구가 진행 중이며, 선진 패키지 제조업체에서 양산 적용을 위하여 가능성을 테스트 단계로 진입하였지만 신뢰성에 대한 문제와 개발분야의 경험부족의 단점으로 인하여 상용화가 더딘 실정이다.

추가적으로, 무연솔더 접합부에서 발생되는 $\mathrm{EM}$ 현 상은 IMC 및 void의 핵생성 및 성장속도와 가장 밀접 한 관계를 가진다. 전류밀도가 높아짐에 따라 솔더 접 합부에서 Joule 가열에 의한 온도 증가의 $\mathrm{TM}$ 효과가 현저하게 증가하므로, $\mathrm{EM}$ 현상 이외에도 $\mathrm{TM}$ 효과 및 응력에 기인하는 stress-migration, 그리고 패키지의 적층에 따른 휨(warpage) 현상 등을 함께 고려할 필 요가 있다. 이를 고려한다면, 패키지의 수명에 대한 신 뢰성을 더욱 향상시킬 수 있을 것으로 판단된다.

\section{4. 결 론}

현재의 패키징 기술을 넘어선 차세대의 패키징 시대 가 도래하면서 기술적으로 극복해야 될 과제들이 존재 한다. 그 중 솔더 접합부에 가장 큰 영향을 미치는 $\mathrm{EM}$ 현상에 의한 결함은 현재까지 보고되어진 문제점 이지만, 패키지의 소형화 및 고밀도화에 따른 요구 조 건의 변화로 인하여 가장 현실적인 문제로 인식되고 있 다. 이를 정리하여 다음과 같은 문제점과 개선사항을 제시한다.

1) 솔더의 무연화가 이루어짐에 따라, 다양한 솔더 접합부에서의 $\mathrm{EM}$ 현상에 대하여 연구되고 있다. 이미 보고된 연구자료에 의하면 무연솔더의 적용이 $\mathrm{Sn}-\mathrm{Pb}$ 솔더 보다 $\mathrm{EM}$ 현상에 대한 저항성이 강한 것으로 판단 된다 ${ }^{61)}$. 다양한 무연솔더 접합부에서 발생되는 $\mathrm{EM}$ 현 상으로 인한 $\mathrm{IMC}$ 와 void의 핵생성 및 성장 속도, 전 류 밀도 및 인가시간 등의 변수에 의한 $\mathrm{EM}$ 속도 예 측, $\mathrm{Sn}$ 성장 방향이 $\mathrm{EM}$ 현상에 미치는 영향 등의 연 구가 추가적으로 이루어져야 $\mathrm{EM}$ 현상에 대한 문제점 이 해결될 수 있을 것으로 판단된다.

2) 이러한 연구를 진행하기 위하여 다양한 연구 장 비가 활용되어져 왔으며, 최근에는 in-situ 이미지를 통하여 시간에 따른 IMC 거동 분석, TEM 분석을 통 한 IMC 거동에 대한 메커니즘 규명 등의 최신 장비를 적용한 분석이 이루어지며, 이러한 분석은 솔더 접합부 에 대한 연구 결과에 대한 신뢰성을 향상시킬 수 있다.

3) 현재까지 다양한 접합부에 대한 연구가 다수 진 행되어 왔으며, ENEPIG 표면처리를 한 기판의 적용 한 경우에 솔더/ENEPIG의 접합 특성이 가장 우수하 
다고 알려져 있으나, 가속화되는 미세피치 기술을 만족 시키기 위하여 ENEPIG의 $\mathrm{Ni}$ 층을 $1 \mu \mathrm{m}$ 이하로 감소 시키는 연구가 진행 중에 있다. 하지만 현재 양산 적용 을 위한 시험 단계 이므로 많은 연구개발이 이루어져야 한다. 그러므로 앞으로의 솔더 접합부에 대한 개발 방 향은 $\mathrm{ENEPIG}$ 의 $\mathrm{Ni}$ 층을 감소시키는 방안을 통하여 집중적으로 연구가 진행 될 것이라 예상된다.

4) 4차산업혁명 시대에 맞추어 ENEPIG와 솔더의 계면에서 $\mathrm{EM}$ 과 $\mathrm{TM}$ 에 의한 $\mathrm{IMC}$ 층과 Kirkendall void 의 성장에 대한 실험결과를 예측할 수 있는 모델링 연 구와 휨(warpage) 연구가 필수적이다.

\section{Acknowledgment}

This work was supported by the Technology Innovation Program - Materials and Components Development Program (Grant No. 20011427) funded by the Korean Ministry of Trade, Industry, and Energy (MOTIE) and Competency Development Program for Industry Specialists of Korea Institute for Advancement of Technology (KIAT) (Grant No. P0002019) in the Republic Korea.

ORCID: Sujong Kim: http://orcid.org/0000-0002-1030-0942 ORCID: Wonsik Hong: http://orcid.org/0000-0001-8398-177X ORCID: Hyunbin Nam: http://orcid.org/0000-0003-3152-9567 ORCID: Namhyun Kang: http://orcid.org/0000-0002-9460-5128

\section{References}

1. M. Kim, Y. Ko, J. Bang and C. Lee, The Chip Bonding Technology on Flexible Substrate by Using Micro Lead-free Solder Bump, J. Microelectron. Packag. Soc. 19(3) (2012) 15-20.

http://dx.doi.org/10.6117/kmeps.2012.19.3.015

2. Y. K. Ko, Y. H. Ko and C. W. Lee, Micro-bump Joining Technology for 3 Dimensional Chip Stacking, $J$. Korean Soc. Precis. Eng. 31(10) (2014) 865-871. http://dx.doi.org/10.7736/KSPE.2014.31.10.865

3. G. Kim, K. Son, G. T. Park, Y. B. Park, Effect of Current Densities on the Electromigration Failure Mechanisms of Flip-Chip Sn-Ag Solder Bump, Korean J. Met. Mater. 55(11) (2017) 798-805.

https://doi.org/10.3365/KJMM.2017.55.11.798

4. J. M. Park, S. H. Kim, M. H. Jeong and Y. B. Park, Effect of $\mathrm{Cu}-\mathrm{Sn}$ intermetallic compound reactions on the Kirkendall void growth characteristics in $\mathrm{Cu} / \mathrm{Sn} / \mathrm{Cu}$ microbumps, Jpn. J. Appl. Phys. 53 (2014) 1-4.

5. G. Ross, V. Vuorinen and M. P-Krokel, Void formation and its impact on $\mathrm{Cu}-\mathrm{Sn}$ intermetallic compound formation, J. Alloy. Compd. 677 (2016) 127-138. https://doi.org/10.1016/j.jallcom.2016.03.193

6. J. H. Lee, N. H. Kang, C. W. Lee and J. H. Kim,
Necessity of Low Melting Temperature Pb-free Solder Alloy and Characteristics of Representative Alloys, $J$. Koran Weld. Join. Soc. 24(2) (2006) 17-28.

7. S. Jin, N. Kang, K. Cho, C. Lee and W. Hong, Behavior of Vibration Fracture for $\mathrm{Sn}-\mathrm{Ag}-\mathrm{Cu}-\mathrm{X}$ Solders by Soldering, J. Koran Weld. Join. Soc. 30(2) (2012) 169173.

http://dx.doi.org/10.5781/KWJS.2012.30.2.169

8. C. Y. Kang, Research Trend in Development of Pb Free Solder, J. Koran Weld. Join. Soc. 13(4) (1995) 1-6.

9. W. Yang, R. W. Messler and L.E. Felton, Microstructure Evolution of Eutectic Sn-Ag Solder Joints, J. Electron. Mater. 23 (1994) 765-772. https://doi.org/10.1007/BF02651371

10. Y. Wang, K. H. Lu, V. Gupta, L. Stiborek, D. Shirley, S. H. Chae, J. Im and P. S. Ho, Effects of Sn grain structure on the electromigration of $\mathrm{Sn}-\mathrm{Ag}$ solder joints, J. Mater. Res. 27(8) (2012) 1131-1141. https://doi.org/10.1557/jmr.2012.10

11. S. H. Kim, B. R. Lee, G. T. Park, J. M. Kim, S, H. Yoo and Y. B. Park, Effects of PCB surface finishes on the Mechanical and Electrical Reliabilities of $\mathrm{Sn}-0.7 \mathrm{Cu}$ $\mathrm{Pb}$-free Solder Bump, J. Microelectron. Packag. Soc. 53(10) (2015) 735-744. https://doi.org/10.6117/kmeps.2012.19.4.057

12. Y. Kim, J. Kwon, D. Yoo, S. Park, D. Lee and D. Lee, Influence of Nickel Thickness and Annealing Time on the Mechanical Properties of Intermetallic Compounds Formed between $\mathrm{Cu}-\mathrm{Sn}$ Solder and Substrate, Korean J. Met. Mater. 55(3) (2017) 165-172. https://doi.org/10.3365/KJMM.2017.55.3.165

13. S. K. Lim, Physical Design for 3D System on Package, IEEE Design and Test of Computers. 22(6) (2005) 532-539. https://doi.org/10.1109/MDT.2005.149

14. M. Dong, F. Santagata, R. Sokolovskij, J. Wei, C. Yuan and $\mathrm{G}$, Zhang, 3D system-in-package design using stacked silicon submount technology, Microelectron. Int. 32(2) (2015) 63-72.

https://doi.org/10.1108/MI.11.2014.0050

15. J. H. Lan, Evolution and Outlook of TSV and 3D IC/Si Integration, $201012^{\text {th }}$ Electronics Packaging Technology Conference, Singapore (2010) https://doi.org/10.1109/EPTC.2010.5702702

16. B. H. L. Chao, X. Zhang, S. H. Chae, P. S. Ho, Recent advances on kinetic analysis of electromigration enhanced intermetallic growth and damage formation in $\mathrm{Pb}$-free solder joints, Microelectron. Reliab. 49(3) (2009) 253-263. https://doi.org/10.1016/j.microrel.2009.01.006

17. S. Baek, Y. Park, C. Oh, E. Chun and N. Kang, Modeling and Experimental Verification of Intermetallic Compounds Grown by Electromigration and Thermomigration for Sn-0.7Cu Solders, J. Electron. Mater. 48(1) (2019) 142-151. 
https://doi.org/10.1007/s11664-018-6786-4

18. S. Li, X. Wang, Z. Liu, Y. Jin, S. Zhang, J. Geng, X. Chen, S. Wu, P. He and W. Long, Corrosion behavior of Sn based lead free solder alloys: a review, J. Mater. Sci. 31 (2020) 9076-9090. https://doi.org/10.1007/s10854-020-03540-2

19. P. Zhang, S. Xue, J. Wang, P. Xue, S. Zhong and W. Long, Effect of Nanoparticles Addition on the Microstructure and Properties of Lead-Free Solders: A Review, Appl. Sci. 9(10) (2019) 1-20. https://doi.org/10.3390/app9102044

20. J. Lee, K. Kim and S. Huh, Development of Sn-Zn Based Low Temperature Lead-Free Solder for Improvement of Oxidation Resistance, J. Korean Weld. Join. Soc. 29(5) (2011) 514-521.

http://dx.doi.org/10.5781/KWJS.2011.29.5.514

21. J. Lee, K. Kim, M. Inoue, J. Jiang and K. Suganuma, Effects of $\mathrm{Ag}$ and $\mathrm{Cu}$ addition on microstructural properties and oxidation resistance of $\mathrm{Sn}-\mathrm{Zn}$ eutectic alloy, J. Alloy. Compd. 454 (2008) 310-320. https://doi.org/10.1016/j.jallcom.2006.12.037

22. R. Darveaux and K. Banerji, Constitutive Relations for Tin-Based-Solder Joints, IEEE Trans. Compon. Hybirds. Manuf. Technol. 15(6) (1992) 1013-1024. https://doi.org/10.1109/33.206925

23. I. Artaki, A. M. Jackson and P. T. Vianco, Evaluation of Lead-Free Solder Joints in Electronic Assemblies, J. Electron. Mater. 23(8) (1994) 757-764. https://doi.org/10.1007/BF02651370

24. J. Y. Park, J. P. Jung and C. S. Kang, The Analysis of the Withdrawal Force Curve of the Wetting Balance Curve, IEEE Trans. Compon. Hybirds. Manuf. Technol. 22(3) (1999) 372-377. https://doi.org/10.1109/6144.796538

25. M. Kim, K. Shin and J. Jung, Research Trends of SnAg Based Pb-Free Solders, J. Weld. Join. 19(1) (2001) 15-20.

26. P. T. Vianco and J. A. Rejent, Properties of Ternary Sn-Ag-Bi Solder Alloys: Part II-Wettability and Mechanical Properties Analyses, J. Electron. Mater. 28(10) (1999) 1138-1143. https://doi.org/10.1007/s11664-999-0251-3

27. J. Lee, H. Kim, Y. Lee and Y. Choi, Interfacial Properties with Kind of Surface Finish and Sn-Ag Based Lead-free Solder, J. Korean Weld. Join. Soc. 27(1) (2009) 20-24. https://doi.org/10.5781/KWJS.2009.27.1.020

28. K. Lee, K. Kim and K. Suganuma, Electro-migration Phenomenon in Flip-chip Packages, J. Microelectron. Packag. Soc. 17(4) (2010) 11-17.

29. R. A. Islam, B. Y. Wu, M. O. Alam, Y. C. Chan and W. Jillek, Investigations on microhardness of $\mathrm{Sn}-\mathrm{Zn}$ based lead-free solder alloys as replacement of $\mathrm{Sn}-\mathrm{Pb}$ solder, J. Alloy. Compd. 392 (2005) 149-158. https://doi.org/10.1016/j.jallcom.2004.08.079
30. M. Date, T. Shoji, M. Fujiyoshi, K. Sato and K. N. Tu, Ductile-to-brittle transition in $\mathrm{Sn}-\mathrm{Zn}$ solder joints measured by impact test, Scr. Mater. 51 (2004) 641645. https://doi.org/10.1016/j.scriptamat.2004.06.027

31. P. Xue, S. Xue, Y. Shen and H. Zhu, Interfacial microstructures and mechanical properties of Sn-9Zn-0.5Ga$\mathrm{xNd}$ on $\mathrm{Cu}$ substrate with aging treatment, Mater. Des. 60 (2014) 1-6. http://dx.doi.org/10.1016/j.matdes.2014.03.052

32. R. S. Lai, K. L. Lin and B. Salam, Suppressing Growth of the Cu5Zn8 Intermetallic Layer in Sn-Zn-Ag$\mathrm{Al}-\mathrm{Ga} / \mathrm{Cu}$ Solder Joints, J. Electron. Mater. 38(1) (2009) 88-92. https://doi.org/10.1007/s11664-008-0579-0

33. X. F. Zhang and J. D. Guo, Reverse polarity effect from effective charge disparity during electromigration in eutectic Sn-Zn solder interconnect, J. Mater. Res. 23(12) (2008) 3370-3378. https://doi.org/10.1557/JMR.2008.0413

34. M. L. Huang, Q. Zhou, N. Zhao, X. Y. Lin and Z. J. Zhang, Reverse polarity effect and cross-solder interaction in $\mathrm{Cu} / \mathrm{Sn}-9 \mathrm{Zn} / \mathrm{Ni}$ interconnect during liquid-solid electromigration, J. Mater. Sci. 49 (2014) 17551763. https://doi.org/10.1007/s10853-013-7862-z

35. M. Huang, Z. Zhang, N. Zhao and X. Feng, Reverse Polarity Effect in $\mathrm{Cu} / \mathrm{Sn}-9 \mathrm{Zn} / \mathrm{Ni}$ Interconnect under High Current Density at High Temperature, 2014 15th International Conference on Electronic Packaging Technology, Chengdu China (2014) https://doi.org/10.1109/ICEPT.2014.6922690

36. M. L. Huang, Z. J. Zhang, N. Zhao and Q. Zhou, A synchrotron radiation real-time in situ imaging study on the reverse polarity effect in $\mathrm{Cu} / \mathrm{Sn}-9 \mathrm{Zn} / \mathrm{Cu}$ interconnect during liquid-solid electromigration, Scr. Mater. 68 (2013) 853-856.

http://dx.doi.org/10.1016/j.scriptamat.2013.02.007

37. S. Kuo and K. Lin, Polarity effect of electromigration on intermetallic compound formation in a $\mathrm{Cu} / \mathrm{Sn}-9 \mathrm{Zn} /$ Cu sandwich, J. Mater. Res. 23(4) (2008) 1087-1 094. https://doi.org/10.1557/jmr.2008.0142

38. M. Zhao, L. Zhang, Z. Lin, M. Xiong and L. Sun, Structure and properties of $\mathrm{Sn}-\mathrm{Cu}$ lead-free solders in electronics packaging, Sci. Technol. Adv. Mater. 29 (2019) 421-444. https://doi.org/10.1080/14686996.2019.1591168

39. F. Hung, T. Lui, L. Chen and N. He, Resonant characteristics of the microelectronic $\mathrm{Sn}-\mathrm{Cu}$ solder, J. Alloy Compd. 457 (2008) 171-176. https://doi.org/10.1016/j.jallcom.2007.03.026

40. L. Yang, Y. Zhang, J. Dai, Y. Jing, J. Ge and N. Zhang, Microstructure, interfacial IMC and mechanical properties of Sn-0.7Cu- $x \mathrm{Al}(x=0-0.075)$ lead-free solder alloy, Mater. Des. 67 (2015) 209-216. 
http://dx.doi.org/10.1016/j.matdes.2014.11.036

41. A. A. El-Daly and A. E. Hammad, Enhancement of creep resistance and thermal behavior of eutectic $\mathrm{Sn}-\mathrm{Cu}$ lead-free solder alloy by $\mathrm{Ag}$ and In-additions, Mater. Des. 40 (2012) 292-298.

http://dx.doi.org/10.1016/j.matdes.2012.04.007

42. M. Heo, N. Kang, S. Park, J. Kim and W. S. Hong, Kinetics of Intermetallic Compounds Growth Induced by Electromigration of $\mathrm{Sn}-0.7 \mathrm{Cu}$ Solder, Korean J. Met. Mater. 54(12) (2016) 908-915. https://doi.org/10.3365/KJMM.2016.54.12.908

43. H. Lee, Y. Chen, Evolution of Ag3Sn intermetallic compounds during solidification of eutectic Sn-3.5Ag solder, J. Alloy. Compd. 509 (2011) 2510-2517. https://doi.org/10.1016/j.jallcom.2010.11.068

44. B. Guo, A. Kunwar, N. Zhao, J. Chen, Y. Wang, H. Ma, Effect of $\mathrm{Ag} 3 \mathrm{Sn}$ nanoparticles and temperature on $\mathrm{Cu}_{6} \mathrm{Sn}_{5}$ IMC growth in $\mathrm{Sn} x \mathrm{Ag} / \mathrm{Cu}$ solder joints, Mater. Res. Bull. 99 (2018) 239-248. https://doi.org/10.1016/j.materresbull.2017.11.022

45. Y. Jung and J. Yu, Electromigration induced Kirkendall void growth in $\mathrm{Sn}-3.5 \mathrm{Ag} / \mathrm{Cu}$ solder joints, J. Appl. Phys. 115 (2014) 083708:1-9. https://doi.org/10.1063/1.4867115

46. Y. Park, J. Bang, C. M. Oh, W. S. Hong and N. Kang, The Effect of Eutectic Structure on the Creep Properties of Sn-3.0Ag- $0.5 \mathrm{Cu}$ and $\mathrm{Sn}-8.0 \mathrm{Sb}-3.0 \mathrm{Ag}$ Solders, Met. 7(12) (2017) 540:1-12. https://doi.org/10.3390/met7120540

47. A. T. Tan, A. W. Tan and F. Yusof, Evolution of microstructure and mechanical properties of $\mathrm{Cu} / \mathrm{SAC} 305 / \mathrm{Cu}$ solder joints under the influence of low ultrasonic power, J. Alloy. Compd. 705 (2017) 188-197. http://dx.doi.org/10.1016/j.jallcom.2017.02.165

48. M. Z. Yahaya, N. A. Salleh, S. Kheawhom, B. Illes, M. F. M. Nazeri and A. A. Mohamad, Selective etching and hardness properties of quenched SAC305 solder joints, Solder. Surf. Mount Technol. 32(4) (2020) 225233.

https://doi.org/10.1108/SSMT-01-2020-0001

49. S. Kim, G. Park, B. Lee, J. Kim, S. Yoo and Y. Park, Effects of PCB Surface Finishes on in-situ Intermetallics Growth and Electromigration Characteristics of Sn-3.0Ag-0.5Cu Pb-free Solder Joints, J. Microelectron. Packag. Soc. 22(2) (2015) 47-53.

http://dx.doi.org/10.6117/kmeps.2015.22.2.047
50. J. Choi, S. Jun, H. Won, B. Jung and T. Oh, Electromigration Behavior of Flip-Chip Bonded Sn-3.5Ag$0.5 \mathrm{Cu}$ Solder Bumps, J. Microelectron. Packag. Soc. 11(4) (2004) 43-48.

51. K. Kim, W. Seo, S. Kwon, J. Kim, J. Yoon and S. Yoo, Effects of Ni-P Bath on the Brittle Fracture of Sn-Ag-Cu Solder/ENEPIG Solder Joint, J. Weld. Join. 35(3) (2017) 1-6. https://doi.org/10.5781/JWJ.2017.35.3.1

52. S. Huh, J. Lee and S. Ham, Reliability of Sn-Ag-Cu Solder Joint on ENEPIG Surface Finish: 1. Effects of thickness and roughness of electroless Ni-P deposit, $J$. Microelectron. Packag. Soc. 21(3) (2014) 43-50. http://dx.doi.org/10.6117/kmeps.2014.21.3.043

53. J. Yoon, B. Noh and S. Jung, Comparative Study of ENIG and ENEPIG as Surface Finishes for a $\mathrm{Sn}-\mathrm{Ag}-\mathrm{Cu}$ Solder Joint, J. Electron. Mater. 40(9) (2011) 1950-1955. https://doi.org/10.1007/s11664-011-1686-x

54. J. Yoon, J. Bang, C. Lee and S. Jung, Interfacial reaction and intermetallic compound formation of Sn-1Ag/ENIG and $\mathrm{Sn}-1 \mathrm{Ag} / \mathrm{ENEPIG}$ solder joints, J. Alloy. Compd. 627 (2015) 276-280. http://dx.doi.org/10.1016/j.jallcom.2014.11.208

55. C. Ho and J. Duh, Quantifying the dependence of Ni(P) thickness in ultrathin-ENEPIG metallization on the growth of $\mathrm{Cu}-\mathrm{Sn}$ intermetallic compounds in soldering reaction, Mater. Chem. Phys. 148 (2014) 21-27. http://dx.doi.org/10.1016/j.matchemphys.2014.06.072

56. J. Back, S. Yoo, D. Han, S. Jung and J. Yoon, Interfacial Reactions and Mechanical Strength of Sn-3.0Ag$0.5 \mathrm{Cu} / 0.1 \mu \mathrm{m}-\mathrm{Ni}$ Thin ENEPIG Solder Joints, J. Weld. Join. 35(6) (2017) 51-58. https://doi.org/10.5781/JWJ.2017.35.6.8

57. J. Kim, S. Jung and J. Yoon, Effect of Ni(P) thickness in $\mathrm{Au} / \mathrm{Pd} / \mathrm{Ni}(\mathrm{P})$ surface finish on the electrical reliability of $\mathrm{Sn}-3.0 \mathrm{Ag}-0.5 \mathrm{Cu}$ solder joints during current-stressing, J. Alloy. Compd. 850 (2021) 156729: $1-11$. https://doi.org/10.1016/j.jallcom.2020.156729

58. J. Back, B. Lee, S. Yoo, D. Han, S. Jung and J. Yoon, Solderability of thin ENEPIG plating Layer for Fine Pitch Package application, J. Microelectron. Packag. Soc. 24(1) (2017) 83-90. https://doi.org/10.6117/kmeps.2017.24.1.083 